\title{
The rediscovery of the rare Vietnamese endemic Eriophorum scabriculme redefines generic limits in the Scirpo-Caricoid Clade (Cyperaceae)
}

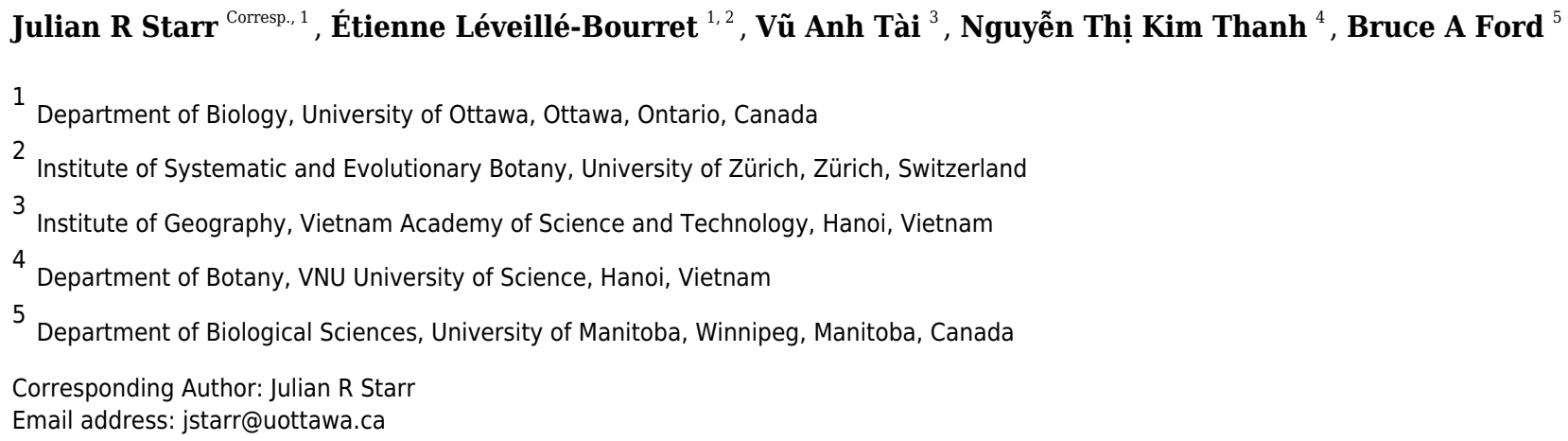

For those familiar with boreal bogs and wet tundra, species of Eriophorum ("the cotton grasses") will undoubtedly represent some of the most striking and memorable taxa they have encountered. This small genus of 20 Holarctic sedge species (Cyperaceae) is remarkable because its inflorescences produce large, brilliantly white to rusty-red cottony masses when its flowers develop a perianth of highly elongated bristles after anthesis. In this study, we document the rediscovery of Eriophorum scabriculme, a narrow Vietnamese endemic known from only two collections made approximately $7 \mathrm{~km}$ apart near Sa Pa in Lào Cai Province over 75 years ago. Using plastid DNA sequences (matK, ndhF), embryology, and morphology, we test whether E. scabriculme is aligned within either the Scirpo-Caricoid Clade (genus Khaosokia and tribes Cariceae, Dulichieae, Scirpeae, and Sumatroscirpeae) or the Ficinia Clade (Cypereae), and we determine whether its unique character combinations ( $\geq 10$ elongated bristles, reduced sheathing basal leaves, $1-4$ spikelets) could be evidence for a new genus or simply mark it as an unusual species within currently recognised genera. In addition, we document the discovery of seven new populations, and we extend its range westward to Lai Châu Province and southward in Lào Cai Province by more than $47 \mathrm{~km}$. Our results demonstrate that Eriophorum scabriculme is best treated in the genus Trichophorum, thus re-circumscribing both genera and their limits with Scirpus s.str. In addition, we emend the description of Trichophorum scabriculme (Beetle) J.R.Starr, Lév.-Bourret \& B.A.Ford, provide the first pictures and accurate illustration of the species, and assess its conservation status in Vietnam (VU, Vulnerable). Our study corroborates the fact that in such a diverse and taxonomically difficult family like the sedges, conspicuous characters like highly elongated bristles may 
be useful for dividing diversity, but they are no guarantee that the groups they mark are natural. 


\section{The rediscovery of the rare Vietnamese endemic}

3 Eriophorum scabriculme redefines generic limits in

4 the Scirpo-Caricoid Clade (Cyperaceae)

5

6

7 Julian R. Starr ${ }^{1}$, Étienne Léveillé-Bourret ${ }^{1,2}$, Vũ Anh Tài ${ }^{3}$, Nguyễn Thị Kim Thanh ${ }^{4}$, Bruce A.

8 Ford $^{5}$

9

$10{ }^{1}$ Department of Biology, University of Ottawa, Ottawa, Ontario, Canada

11 Institute of Systematic and Evolutionary Botany, University of Zürich, Zürich, Switzerland

12 Institute of Geography, Vietnam Academy of Science and Technology, Hanoi, Vietnam

${ }^{4}$ Department of Botany, VNU University of Science, Hanoi, Vietnam

${ }^{5}$ Department of Biological Sciences, University of Manitoba, Winnipeg, Manitoba, Canada

Corresponding author:

17 Julian Starr ${ }^{1}$

1830 Marie Curie, Ottawa, Ontario, K1N 6N5, Canada

Email address: jstarr@uottawa.ca. 


\section{Abstract}

22

For those familiar with boreal bogs and wet tundra, species of Eriophorum ("the cotton grasses") will undoubtedly represent some of the most striking and memorable taxa they have encountered. This small genus of 20 Holarctic sedge species (Cyperaceae) is remarkable because its inflorescences produce large, brilliantly white to rusty-red cottony masses when its flowers develop a perianth of highly elongated bristles after anthesis. In this study, we document the rediscovery of Eriophorum scabriculme, a narrow Vietnamese endemic known from only two collections made approximately $7 \mathrm{~km}$ apart near Sa Pa in Lào Cai Province over 75 years ago. Using plastid DNA sequences ( $m a t K, n d h F$ ), embryology, and morphology, we test whether $E$. scabriculme is aligned within either the Scirpo-Caricoid Clade (genus Khaosokia and tribes Cariceae, Dulichieae, Scirpeae, and Sumatroscirpeae) or the Ficinia Clade (Cypereae), and we determine whether its unique character combinations ( $\geq 10$ elongated bristles, reduced sheathing basal leaves, $1-4$ spikelets) could be evidence for a new genus or simply mark it as an unusual species within currently recognised genera. In addition, we document the discovery of seven new populations, and we extend its range westward to Lai Châu Province and southward in Lào Cai Province by more than $47 \mathrm{~km}$. Our results demonstrate that Eriophorum scabriculme is best treated in the genus Trichophorum, thus re-circumscribing both genera and their limits with Scirpus s.str. In addition, we emend the description of Trichophorum scabriculme (Beetle) J.R.Starr, Lév.-Bourret \& B.A.Ford, provide the first pictures and accurate illustration of the species, and assess its conservation status in Vietnam (VU, Vulnerable). Our study corroborates the fact that in such a diverse and taxonomically difficult family like the sedges, conspicuous characters like highly elongated bristles may be useful for dividing diversity, but they are no guarantee that the groups they mark are natural. 


\section{Introduction}

For those familiar with boreal bogs and wet tundra, species of Eriophorum L. ("the cotton grasses") will undoubtedly represent some of the most striking and memorable taxa they have encountered. This small group of 20 Holarctic sedge species (Cyperaceae Juss.) is remarkable because its compound to unispicate infructescences form large, silky white to rusty-red cottony masses due to perianth bristles that elongate after anthesis. These bristles remain attached to the fruits and are probably involved in wind dispersal (Kern, 1974; Fridriksson, 1982; Goetghebeur, 1998; pers. obs.) and possibly heat retention (Simonis et al., 2014; Small \& Cayouette, 2016). They also make Eriophorum one of the easiest of sedge genera to recognise for amateurs and professionals alike. Nevertheless, the circumscription of the genus remains unclear. Conspicuous characters may be useful for dividing sedge diversity, but there is no guarantee that the groups they mark are natural (Starr, Harris \& Simpson, 2004; Larridon et al., 2013; Starr, Janzen \& Ford, 2015).

The circumscription of Eriophorum is intimately linked to the circumscription of the genus Scirpus L., its closest ally and a taxon with a difficult taxonomic history. In the broad sense, Scirpus consisted of a heterogeneous group of over 250 species and more than 50 modern genera (Koyama, 1958; Schuyler, 1971; Dhooge, 2005), whose defining features are now believed to be plesiomorphies (spirally arranged scales, bisexual flowers with perianth parts absent or reduced to bristles and scales, and terete spikelets) (Goetghebeur, 1986; Muasya et al., 2009; Léveillé-Bourret \& Starr, in press). Eriophorum shared these characteristics with Scirpus s.1., but with exception of Koyama (1958), it was not placed in the synonymy of Scirpus largely because any sedge with long bristles and scirpoid features could be conveniently positioned within Eriophorum.

The limits of Eriophorum and Scirpus became clearer when evidence from embryo types (van der Veken, 1965), fruit epidermal silica bodies (Schuyler, 1971) and inflorescence structure (Bruhl, 1995; Goetghebeur, 1986, 1998) began to suggest that Scirpus s.l. should be divided into multiple, often distantly related genera. The first molecular phylogenies for Cyperaceae (Muasya et al., 1998, 2000) confirmed this, and the definition of Scirpus was eventually restricted to a Holarctic genus consisting of ca. 50 species that shared a Fimbristylis-type embryo (i.e., when known), noded culms, small spikelets in open anthelodia, and generally six perianth parts in the form of bristles when present (Dhooge, 2005; Muasya et al., 2009; Léveillé-Bourret \& Starr, in press). Nonetheless, the limits of Eriophorum remained unsatisfactory because only one character, bristle number, seemingly provided a reliable means for separating it from Scirpus ( 0 or $\leq 6=$ Scirpus $; \geq 10$ = Eriophorum; Goetghebeur, 1998). As family relationships became ever clearer, the most problematic taxa blurring their limits were slowly eliminated such that a focus on an even narrower range of taxa was possible. Studies demonstrated that morphologically confusing species of Scirpus or Eriophorum were separate generic lineages related either to elements in the distantly related Ficinia Clade of tribe Cypereae (Muasya et al., 2012; Yano et 
82

83

84

85

86

87

al., 2012; Garcia-Madrid et al., 2015), or closely allied to Scirpus and Eriophorum within the Scirpo-Caricoid Clade or "SCC" (i.e., the Cariceae-Dulichieae-Scirpeae Clade, renamed for recent changes in tribal classification; Léveillé-Bourret, Starr \& Ford, 2018; Léveillé-Bourret \& Starr, in press), a cosmopolitan group of more than 2,250 species and eight major lineages (Dulichieae, Khaosokia, Calliscirpus, Cariceae, Sumatroscirpeae, Trichophorum Clade, Zameioscirpus Clade, and Scirpus+Eriophorum Clade; Dhooge, Goetghebeur \& Muasya, 2003; Gilmour, Starr \& Naczi, 2013; Léveillé-Bourret et al., 2015; Semmouri et al., 2019).

These close relatives in the SCC represent the biggest problem for circumscription because they often possess seemingly intermediate characteristics. Over the past 30 years, five of these close allies have been recognised as separate genera. Calliscirpus C.N. Gilmour, J.R. Starr \& Naczi, which blurred the limits of Scirpus and Eriophorum because it possesses lightly scabrous bristles (normally smooth in Eriophorum) intermediate in length and variable in number (6, rarely up to 12), is now known to represent a relatively distant lineage in the SCC (Gilmour, Starr \& Naczi, 2013; Léveillé-Bourret et al., 2014; Léveillé-Bourret \& Starr, in press). In contrast, the recent Scirpus segregates Zameioscirpus Dhooge \& Goetgh. and Rhodoscirpus Lév.-Bourret, Donadío \& J.R.Starr are part of a molecularly and morphologically well-supported clade that includes Amphiscirpus and Phylloscirpus as sister to Scirpus and Eriophorum. Although Zameioscirpus, Amphiscirpus, and Phylloscirpus are morphologically distinctive (generally small and reduced, basal leaves, capitate to unispicate inflorescences), the gross morphology of Rhodoscirpus (e.g., large size, cauline leaves, open anthelae) resembles Scirpus s.str. to such a degree that the modern limits of Scirpus may still need to be redefined (LéveilléBourret et al., 2015; Léveillé-Bourret \& Starr, in press). The remaining two genera, Cypringlea M.T. Strong and Oreobolopsis T.Koyama \& Guagl., appear to be aligned with Trichophorum Pers. (Strong, 2003; Dhooge, Goetghebeur \& Muasya, 2003; Léveillé-Bourret et al., 2014; Semmouri et al., 2019), another genus that has been closely linked to the circumscription of Scirpus and Eriophorum.

Although Trichophorum has features that can separate it from Scirpus and Eriophorum, such as a reduced habit and sheathed basal leaves with poorly developed blades, its species share many important characteristics with Scirpus and Eriophorum. For example, Trichophorum species may or may not possess six or fewer short, serrrulate bristles as in Scirpus, and at least one species, T. schansiense Handel-Mazzetti, is reported to have more than six bristles (7-9) like an Eriophorum (Liang \& Tucker, 2010b). Another species, T. alpinum (L.) Pers., has six bristles like a Scirpus, but they are long, silky and flattened like an Eriophorum, which explains why it has long been treated as a Scirpus and an Eriophorum (Schuyler, 1971). Moreover, inflorescences in the genus typically consist of a single terminal spikelet similar to Eriophorum p.p. (e.g., E. vaginatum L.), but a few short-bristled Southeast Asian species recently transferred from Scirpus can have as many as four to six (i.e., T. subcapitatum (Thwaites \& Hooker) D. A. Simpson and T. mattfeldianum (Kükenthal) S. Yun Liang; Simpson, 1998; Fu, 2009). 
Even their ecology suggests a close affinity. All three genera are common in boreal bogs, although only Eriophorum and Trichophorum grow on arctic and alpine tundra, and unlike either Scirpus or Eriophorum, a few Trichophorum are found on rock faces and ledges (Lee and Oh, 2006; Jung and Choi, 2010; pers. obs.), an unusual habitat for sedges. Nonetheless, despite the many interesting similarities noted above, Trichophorum differs markedly in its embryology, which is often a diagnostic character for determining generic or even tribal affinities in sedges (Goetghebeur, 1986; Goetghebeur, 1998; Semmouri et al., 2019). Whereas Trichophorum shares a Carex-type embryo with its close allies Cypringlea and Oreobolopsis (van der Veken, 1965; Strong, 2003; Dhooge, 2005), Scirpus and Eriophorum possess a Fimbristylis-type embryo (van der Veken, 1965; Goetghebeur, 1986), suggesting that ultimately they are more closely related to each other than to Trichophorum.

Molecular data has since confirmed there is a close relationship between Eriophorum p.p. and Scirpus s.str. (Gilmour, Starr \& Naczi, 2013; Léveillé-Bourret et al., 2014). Of the four Eriophorum subgenera currently recognised (Eriophorum, Eriophoropsis (Palla) Raymond, Phyllanthela (Anderss.) Egor., Erioscirpus (Palla) Raymond; Novoselova, 1994a; Novoselova, 1994b), species from the temperate subgenera Eriophorum, Eriophoropsis, and Phyllanthela form a strongly supported clade nested in Scirpus. Whether these subgenera are best treated in Scirpus remains to be seen (Léveillé-Bourret et al., 2015; Léveillé-Bourret \& Starr, in press), but their monophyly is strongly corroborated by other data such as morphology (a simple anthela or a single spikelet, $>10$ long, smooth, perianth bristles), embryology (Fimbristylis-type embryo), ecology (bogs, tundra) and bristle development (Mora-Osejo, 1987; Vrijdaghs et al., 2005).

In contrast, the members of Eriophorum subgenus Erioscirpus (Palla) Raymond, a small, tropical to subtropical Southeast Asian group of four species (E. scabriculme (Beetle) Raymond, E. comosum (Wall.) Nees in R.Wight, E. microstachyum Boeckeler, E. transiens Raymond), differ markedly from all other Eriophorum in morphology (e.g., bristles barbed; Goetghebeur, 1998; Pers. Obs.), embryology (van der Veken, 1965; Goetghebeur, 1986; Bruhl, 1995) and ecology, as all species are common to rocky slopes and walls (Raymond, 1957; Raymond, 1959a; Noltie, 1994; Liang, Tucker-Drob \& Simpson, 2010; pers. obs.). In agreement with their atypical features for Eriophorum, molecular data has recently demonstrated that E. comosum and E. microstachyum are closely related to Scirpus segregates in the Ficinia Clade of tribe Cypereae and are thus best treated as a separate genus, Erioscirpus Palla (Yano et al., 2012). Eriophorum transiens is only known from its type (J. Esquirol 4367, P!), but its small spikelets arranged in dense glomerules, its long wispy bracts, and basally fused barbed bristles (Raymond, 1959a; Noltie, 1994; pers. obs.) suggests an affinity to species in the Ficinia Clade like several of the Scirpus segregates noted above. Consequently, only Eriophorum scabriculme still blurs the limits between Eriophorum and Scirpus.

Eriophorum scabriculme is a narrow Vietnamese endemic that is known from only two collections made approximately $7 \mathrm{~km}$ apart near Sa Pa in Lào Cai Province over 75 years ago (Pételot 6128 \& 8636, GH!, MT!, P!, L!). Unlike the other members of Eriophorum subg. 
159

160

161

162

163

164

165

166

167

168

169

170

171

172

173

174

175

176

177

178

179

180

181

182

183

184

185

\section{6}

187

193

Erioscirpus, E. scabriculme shows a clear morphological affinity to species in the SCC clade. Like Eriophorum, it possesses numerous ( $\geq 10$ ) long, silky bristles, but similar to Trichophorum, it is a small plant with sheathing basal leaves and reduced blades that has a limited number of spikelets (1-4) in its inflorescence. Moreover, like a few Trichophorum species, it lives on rocky vertical habitats like slopes and cliffs.

In this study, we document the re-discovery of Eriophorum scabriculme during two field seasons in Northern Vietnam. Using DNA sequences, embryology, and morphology we test whether E. scabriculme is best treated as an Eriophorum or in allied genera, whether it should be aligned with Erioscirpus species in the Ficinia Clade, or whether its unique character combinations could be evidence for a new generic lineage in Cyperaceae. The results of our analyses clearly demonstrate that E. scabriculme is not related to either Erioscirpus species or to other Eriophorum, but represents an unusual species in the genus Trichophorum. We thus transfer the species to the genus Trichophorum as T. scabriculme (Beetle) J.R. Starr, Lév.Bourret \& B.A. Ford, clarifying the limits of both Trichophorum and Eriophorum. In addition, we document the discovery of seven new populations, extending its range to over $47 \mathrm{~km}$, including two populations from Lai Châu, the province adjacent to Lào Cai. We emend the description of T. scabriculme, provide an illustration of the species, assess its conservation status, and provide a key to the Trichophorum in Vietnam and southern China.

\section{Materials \& Methods}

\section{Collection and exportation permits}

All Vietnamese samples used in this study were collected and exported under permit numbers 222/TCLN-BTTN (2012) and 184/TCLN-BTTN (2015), which were issued by the Vietnamese Forest Protection Department with the support of the faculty and staff at VNU University of Science, Hanoi. Vouchers for all taxa used in this study are available in publicly accessible herbaria (Table S1).

\section{E-publication and nomenclature}

The electronic version of this article in Portable Document Format (PDF) will represent a published work according to the International Code of Nomenclature for algae, fungi, and plants (ICN), and hence the new names contained in the electronic version are effectively published under that Code from the electronic edition alone. In addition, new names contained in this work which have been issued with identifiers by IPNI will eventually be made available to the Global Names Index. The IPNI LSIDs can be resolved and the associated information viewed through any standard web browser by appending the LSID contained in this publication to the prefix 
194

195

196

197

198

199

200

201

202

203

204

205

206

207

208

209

210

211

212

213

214

215

216

217

218

219

220

221

222

223

224

225

226

227

228

"http://ipni.org/". The online version of this work is archived and available from the following digital repositories: PeerJ, PubMed Central, and CLOCKSS.

\section{Taxonomic sampling, molecular markers, and outgroup selection}

To determine the generic position of Eriophorum scabriculme (hereafter referred to as Trichophorum scabriculme), taxa were selected to fully represent the morphological and geographical diversity of all seven major lineages discovered in previous molecular analyses focused on the SCC clade (Gilmour, Starr \& Naczi, 2013; Léveillé-Bourret et al., 2015; LéveilléBourret et al., 2014; Léveillé-Bourret, Starr \& Ford, 2018) (Table S1). To test whether Trichophorum scabriculme could be related to Erioscirpus as suggested by many previous authors (Raymond, 1957; Koyama, 1958; Novoselova, 1994a), Erioscirpus comosus was included in all analyses. Portions of the rapidly evolving plastid genes mat $K$ and $n d h F$ were used in all analyses as these markers have been shown to be highly useful for determining generic placement within the SCC (Gilmour, Starr \& Naczi, 2013; Léveillé-Bourret et al., 2015; Léveillé-Bourret et al., 2014).Outgroups were selected using the results of previous family-wide analyses of Cyperaceae (Muasya et al., 1998; Muasya et al., 2009).

\section{DNA Extraction, PCR Amplification, Sequencing and Alignment}

Genomic DNA was extracted from herbarium or field-collected (silica-dried) leaf tissue following the silica-column based protocol of Alexander et al. (2007) as modified by Starr, Naczi \& Chouinard (2009). PCR and sequencing protocols for matK and $n d h F$ follow Gilmour, Starr \& Naczi (2013) and Léveillé-Bourret et al. (2014).

Sequence chromatograms were assembled and corrected in Geneious 8.1.9. Alignments were made using MAFFT version 7.017b (Katoh \& Standley, 2013), concatenated by species, and then adjusted by hand using parsimony as an objective criterion (Starr, Harris \& Simpson, 2004).

\section{Phylogenetic Analyses}

Both parsimony and maximum likelihood (ML) analyses were conducted on the combined matK $+n d h F$ matrix. For parsimony analyses, heuristic searches were conducted in PAUP* version $4.0 \mathrm{~b} 10$ (Swofford, 2003) using a random addition sequence of taxa for 2,000 replicates with the MULTREES option on and no more than 10 trees saved per replicate. Relationships were evaluated from a strict consensus tree produced in PAUP*. Branch support was evaluated from 10,000 heuristic bootstrap replicates with the MULTREES option turned off (DeBry \& Olmstead, 2000), and the level of BS support was subjectively described as follows: strong 95- 
$229100 \%$ BS; very good 85-94\% BS; good $75-84 \%$ BS; moderate $65-74 \%$ BS; weak $55-64 \%$ 230 BS; and very weak $<55 \%$ BS (Starr, Harris \& Simpson, 2004).

Concatenated ML analyses were performed with RAxML version 8.2.12 (Stamatakis, 232 2014). The partitioning scheme was selected among all codon and locus subsets with 233 PartitionFinder version 2.1.1 (Lanfear et al., 2012) constraining the model for each partition to 234 be either GTR or GTR $+\mathrm{G}$, and using RAxML for partitioning scheme comparisons. RAxML 235 searches were made with 200 randomized maximum parsimony starting trees and the old and 236 slower, but more accurate, rapid hill—climbing algorithm (option -f o). Branch support was 237 assessed with 2,000 standard bootstrap replicates (Felsenstein, 1985).

238 The $m a t K+n d h F$ data matrix used in analyses is provided as supplemental information 239 with this article (Data S1). DNA sequences were submitted to GenBank (Table S1). 
241

242

243

244

245

246

247

248

249

250

251

252

253

254

255

256

257

258

259

260

261

262

263

264

265

266

267

268

269

270

271

272

273

274

275

\section{Morphological studies, botanical illustration and taxonomic key}

The protologue for Trichophorum scabriculme (as Eriophorum scabriculme; Beetle, 1946) was based on an immature specimen, which explains why Raymond (1957) emended the description when he received more complete specimens years later. However, discrepancies between Raymond's emended description and observations made by us in the field (e.g., bristle and anther number) suggested that a more thorough description of the species using all known material was necessary. The holotype and the specimens used by Raymond (1957) were included in the preparation of the description. In addition, a detailed illustration of T. scabriculme was made as one was not included with the protologue or in Raymond (1957). The only illustration for Trichophorum scabriculme (Pham, 1993) does not appear to have been made from a live plant or specimen.

A key to the genus Trichophorum in Vietnam and southern China was developed from the literature and specimen data. Trichophorum subcapitatum is part of a difficult and variable East and Southeast Asian group that has been variously treated by authors, with distinguishing characters often subtle and intergrading (Beetle, 1946; Kern, 1956; Kern, 1974; Liang \& Tucker, 2010b). It includes Trichophorum mattfeldianum, which is segregated based on the presence of (obtusely) trigonous culms, but most specimens of the group have at least slightly roundedtrigonous culms near the base, and this characteristic does not appear to be correlated with other morphological differences, despite claims to the contrary. A revision of the morphological variation of the complex, which includes Scirpus clarkei Stapf., S. morrisonensis Hayata, S. pulogensis Merr., S. pakapakensis Stapf. and S. subcapitatus subsp. celebicus J.Kern, is therefore needed before a taxonomic system can be proposed. We thus refer all these taxa to the "Trichophorum subcapitatum agg." in our key.

\section{Embryology}

Embryo morphology is well characterised in the SCC (van der Veken, 1965; Goetghebeur, 1986; Dhooge, 2005; Gilmour, Starr \& Naczi, 2013; Semmouri et al., 2019), and it is an excellent tool for testing hypotheses of generic and tribal placement when used in conjunction with other data. Embryos from Trichophorum scabriculme were prepared and visualised following Gilmour, Starr \& Naczi (2013) and the embryo type was determined following the type designations described in Goetghebeur (1986) and Dhooge (2005).

\section{Range and habitat descriptions}

All known populations and collections of Trichophorum scabriculme were mapped using GPS coordinates or specimens that could be georeferenced to $<1 \mathrm{~km}$ area of uncertainty (a few 
276

277

278

279

280

281

282

283

284

285

286

287

288

289

290

291

292

293

294

295

296

297

exceptions are noted below under Conservation Status). Collections were only considered to represent separate populations when contiguous collections were more than $1 \mathrm{~km}$ part. Multiple collections made near Ô Quy Hồ Pass and Tiên Sa Waterfall were thus considered to be just two populations. Habitat descriptions for T. scabriculme were characterised from specimen labels and field experience in Vietnam.

\section{Conservation Status}

The conservation status of Trichophorum scabriculme was assessed according to the criteria outlined in IUCN Red List Categories and Criteria: Version 3.1 (IUCN, 2012). GeoCAT (Bachman et al., 2011) was used to determine the extent of occurrence for T. scabriculme based on specimens that represented unique localities with GPS coordinates or specimens that could be georeferenced to a $<1 \mathrm{~km}$ area of uncertainty with three exceptions. These included a specimen from Lai Châu Province (N.T. Hiep, P.H. Hoang \& L. Averyanov 2846, MO) whose locality was roughly estimated from label data because it represented one of only two populations known from this province, and two observations of individuals that were too immature or too mature to warrant collecting, but for which georeferenced pictures (GPS) were taken. Full locality data for the two observations without collections is given under the "Notes" section of the Taxonomic Treatment below. This data is also available in the GeoCAT file of all documented localities that was submitted as supplemental Data S2.The number of unique populations known to occur within or outside protected areas was determined using the World Database on Protected Areas (IUCN \& UNEP, 2014) as a layer in GeoCAT. 
298

299

300

301

302

303

304

305

306

307

308

309

310

311

312

313

314

315

316

317

318

319

320

321

322

323

324

325

326

327

328

329

330

331

332

333

\section{Results}

\section{Phylogenetic analyses}

The alignment of $m a t K+n d h F$ sequences for 72 taxa produced a data matrix of 2,534 characters of which 1,671 were constant and 513 were parsimony informative. Heuristic parsimony searches recovered 3,346 most parsimonious trees of 1,721 steps $(C I=0.63 ; \mathrm{RI}=0.76)$. The best scoring scheme in PartitionFinder $(\mathrm{BIC}=28,360.2879946)$ included two GTR+Gamma partitions: (1) codon positions 1 and 2 of matK and $n d h F$, and (2) codon position 3 of matK and $n d h F$. The best-scoring ML tree had a log-likelihood of -13,582.242449.

Parsimony and ML analyses were fully compatible with the ML tree being more resolved than the strict consensus of parsimony analyses. For example, both analyses placed

Trichophorum alpinum, the T. subcapitatum agg. and T. scabriculme in the same clade with good support, but whereas ML analyses had T. alpinum as sister to T. scabriculme (ML-BS 55\%), this node was lacking in the strict consensus of parsimony analyses. Since these differences did not affect the interpretation of results, the more resolved ML tree is presented with parsimony and ML bootstrap values given above and below branches (Fig. 1). The subjective description of clade support was only based on the values for parsimony as support values are similar for each method of analysis.

The tree in Fig. 1 shows the eight major lineages identified in the analysis of LéveilléBourret, Starr \& Ford (2018) with similar levels of support; namely, Dulichieae (Blysmus, Dulichium), Khaosokia, Calliscirpus, a Zameioscirpus Clade (Phylloscirpus, Rhodoscirpus, Amphiscirpus, Zameioscirpus), a Scirpus + Eriophorum Clade, Sumatroscirpeae, Cariceae and a Trichophorum Clade (Cypringlea, Trichophorum, Oreobolopsis). Trichophorum scabriculme is positioned within a strongly supported Trichophorum Clade, and within a subclade with good support consisting of the Southeast Asian T. subcaptitatum agg. and the circumboreal $T$. alpinum, which is the type for the genus (hereafter the "Trichophorum scabriculme Clade") (Salmenkallio \& Kukkonen, 1989). This clade is sister to a moderately supported clade of all other included Trichophorum species (circumboreal, South American, Asian), as well as species of Cypringlea (Mexican) and Oreobolopsis (South America), although relationships are not well supported or resolved. All sequenced individuals of Trichophorum scabriculme were placed in a single strongly supported clade and displayed no sequence variation in the markers chosen. Topologies clearly demonstrate that $T$. scabriculme is not a member of either the genus Eriophorum or Erioscirpus.

\section{Embryology}

The embryos of T. scabriculme were turbinate (top-shaped) in outline, and possessed a basally positioned root cap and a laterally positioned first leaf (Fig. 2). This clearly identifies them as a

Peer) reviewing PDF | (2019:04:36328:1:1:NEW 17 Jul 2019) 
334 Carex-type embryo (van der Veken, 1965; Goetghebeur, 1986; Dhooge, 2005; Semmouri et al., 335 2019).

336

337

338

339

340

341

342

343

344

345

346

347

348

349

350

351

352

353

354

355

356

357

358

359

360

\section{Morphology}

The specimens examined differed significantly in culm shape, and in the length and number of bristles as compared to the description of these characters in Beetle (1946) and Raymond (1957), and in the illustration of the species provided by Pham (1993). The number of anthers (1) has not been reported before. These differences are discussed below under the section "Notable morphological differences with previous descriptions and illustrations". An illustration (Fig. 3) and emended description of T. scabriculme is provided in the Taxonomic Treatment.

\section{Species distributions and habitat descriptions}

Nine unique populations were documented from 16 collections in two Vietnamese provinces and four Districts (Lào Cai Province, Sa Pa and Văn Bàn Districts; Lai Châu Province, Tam Đường and Tân Uyên Districts) (Fig. 4). All populations are known from the Hoàng Liên Mountains $(612 \mathrm{~m}$ to $2878 \mathrm{~m})$ in full sun on vertical rock walls and rocky road cuts, along steep cascading streams and around waterfalls (Fig. 5). Plants typically grow in a moist, mossy substrate.

\section{Conservation Status and Species Distribution}

Five of nine total populations are within protected areas (Hoang Lien National Park), but all of these populations are heavily influenced by human activity (Fig. 6). The extent of occurrence of the species is $252.8 \mathrm{~km}^{2}$ over a north to south-south west axis of $47 \mathrm{~km}$. A GeoCAT file containing all the specimens and georeferenced photos used to assess the extent of occurrence and conservation status of Trichophorum scabriculme are provided in supplemental information Data S2. This file will be available on the first author's website and it will be updated when further documented specimens are discovered. 


\section{Discussion}

362

363

364

365

366

367

368

369

370

371

372

373

374

375

376

377

378

379

380

381

382

383

384

385

386

387

388

389

390

391

392

393

394

395

396

397

\section{The limits of Eriophorum and Trichophorum are clarified by the transfer of Eriophorum} scabriculme to Trichophorum

Despite its status as one of the oldest (Linnaeus, 1753) and most recognisable genera in Cyperaceae, confusion over how to circumscribe the genus Eriophorum has persisted to this day. This confusion is intimately related to the circumscription of Scirpus s.1., a heterogeneous taxon consisting of over 50 modern genera and more than 250 species (Koyama, 1958; Schuyler, 1971; Dhooge, 2005). Eriophorum shared the defining characteristics of Scirpus s.1., but authors consistently kept Eriophorum separate from Scirpus, except Koyama (1958) because any sedge with scirpoid features and long bristles could be conveniently placed within it, and most Eriophorum species were well known, north-temperate taxa with a clear morphological relationship.

The modern circumscription of Scirpus, which is based on multiple lines of evidence from embryo types (van der Veken, 1965), fruit epidermal silica bodies (Schuyler, 1971) inflorescence structure (Bruhl, 1995; Goetghebeur, 1986, 1998) and molecular phylogeny (Muasya et al., 2009; Muasya et al., 2000), has considerably narrowed the problem. Recent studies have consistently demonstrated that morphologically confusing Scirpus or Eriophorum species were typically separate generic lineages related to either species in the distantly related Ficinia Clade of Cypereae (Muasya et al., 2012; Yano et al., 2012; García-Madrid et al., 2015), or closely allied to Scirpus and Eriophorum within the SCC, a cosmopolitan group comprising eight major lineages (Dulichieae, Khaosokia, Calliscirpus, Sumatroscirpeae, Cariceae, Trichophorum Clade, Zameioscirpus Clade, and Scirpus+Eriophorum Clade; Dhooge, Goetghebeur \& Muasya, 2003; Gilmour, Starr \& Naczi, 2013; Léveillé-Bourret et al., 2015; Léveillé-Bourret, Starr \& Ford, 2018; Semmouri et al., 2019). Several of these lineages were clearly separate from Scirpus and Eriophorum and their allies in tribe Scirpeae, such as tribes Cariceae, Dulichieae and Sumatroscirpeae, and the morphologically unusual genus Khaosokia, but the relationships of the remaining elements were not clear because the limits of Scirpus and Eriophorum remained ill-defined. Moreover, molecular phylogenies suggested that tribe Scirpeae was paraphyletic with respect to the large and morphologically uniform tribe Cariceae, which contains the well-known genus Carex L. ( 2150 species; e.g., Léveillé-Bourret et al., 2014; Léveillé-Bourret et al., 2018). The segregation of Zameioscirpus, Amphiscirpus, Phylloscirpus and Rhodoscirpus (all in South America) from Scirpus (Oteng-Yeboah, 1974; Dhooge, Goetghebeur \& Muasya, 2003; Léveillé-Bourret et al., 2015), and the transfer of the transitional Eriophorum crinigerum Beetle (six, sometimes more, lightly serrulate bristles of intermediate length) to a new genus Calliscirpus (Gilmour, Starr \& Naczi, 2013), were key steps in clarifying the limits between Scirpus and Eriophorum because the challenge could now be restricted to relatively large, north-temperate plants. Even so, bristle number still provided the

Peer] reviewing PDF | (2019:04:36328:1:1:NEW 17 Jul 2019) 
398

399

400

401

402

403

404

405

406

407

408

409

410

411

412

413

414

415

416

417

418

419

420

421

422

423

424

425

426

427

428

429

430

431

432

433

434

435

436

only reliable means for distinguishing species of Scirpus from those in Eriophorum ( 0 or $\leq 6=$ Scirpus; $\geq 10$ = Eriophorum; Goetghebeur, 1998).

Past attempts to reliably separate Scirpus and Eriophorum have combined bristle number with bristle length, or have tried to correlate these characters with other vegetative and reproductive features. A prime example of how changing generic concepts have failed to draw a reliable line between Scirpus and Eriophorum is provided by Scirpus maximowiczii C.B. Clarke. In his protologue for the species, Clarke (1908) noted that except for its six lightly scabrous bristles just surpassing the nutlet, $S$. maximowiczii had more in common with species of Eriophorum. Subsequent authors agreed that when bristle length was assessed within the context of its habitat preferences (wet montane meadows), achene size, and vegetative morphology (e.g., large pendulous spikelets, scarious blackish glumes), $S$. maximowiczii was best placed in the genus Eriophorum (Beetle, 1946; Koyama, 1958; Oteng-Yeboah, 1974). Today, however, treatments universally place this species in Scirpus (e.g., Egorova, 2004; Liang \& Tucker, 2010a; Hoshino, Masaki \& Nishimoto, 2011) because the line between Scirpus and Eriophorum is again focused on bristle number. The failure to find generic characters that could reliably divide species into either Scirpus or Eriophorum can now be explained by fact that Eriophorum may be monophyletic, but it is deeply nested in Scirpus (Gilmour, Starr \& Naczi, 2013; Léveillé-Bourret et al., 2014). Consequently, it would appear that the defining features for Scirpus s.str. are plesiomorphies (Léveillé-Bourret \& Starr, in press). Whether the distinctive genus Eriophorum should be maintained awaits further study, but it would require the naming of at least six to eight new genera to make Scirpus monophyletic (Léveillé-Bourret et al., 2015).

The strong focus on bristle number and length in the circumscription of Eriophorum and Scirpus is the only reasonable way to explain why past authors placed Erioscirpus species, Trichophorum scabriculme and Eriophorum transiens in Eriophorum. They may share long, numerous bristles, a common distribution, and a somewhat similar habitat (rock faces; though Erioscirpus comosum = dry, Trichophorum scabriculme = humid; Pers. Obs.), but they share very little else with each other or Eriophorum s.str. (Table 1). Even the character that seemingly unites them the best, their long, numerous bristles, appears to be no indication of relationship. We can confirm from direct observations of wind dispersing fruits of Trichophorum scabriculme (B. Ford 15053 et al., WIN) and Erioscirpus comosus (B. Ford 1269 et al., WIN) that their distinctive bristles are most likely a convergent adaptation to wind dispersal (Kern, 1974; Goetghebeur, 1998; Yano et al., 2012).

In contrast, the position of Trichophorum scabriculme within the Trichophorum clade and in a monophyletic group with $T$. alpinum and the $T$. subcapitatum agg. is entirely consistent with embryology, morphology, and biogeography. The Carex-type embryo of T. scabriculme is common to all species in the SCC clade except the Eriophorum + Scirpus and Zameioscirpus Clades, sister groups that share the morphologically similar Fimbristylis- and Schoenus-type embryos (van der Veken, 1965; Strong, 2003; Dhooge, 2005; Gilmour, Starr \& Naczi, 2013). Morphologically, the position of Trichophorum scabriculme within a clade that includes the $T$.

Peer] reviewing PDF | (2019:04:36328:1:1:NEW 17 Jul 2019) 
437

438

439

440

441

442

443

444

445

446

447

448

449

450

451

452

453

454

455

456

457

458

459

460

461

462

463

464

465

466

467

468

469

470

471

472

473

474

subcapitatum agg. is consistent with the fact that these are the only taxa in Trichophorum to have more than one spikelet per inflorescence and they are among the few species in Trichophorum to grow on damp rock faces and ledges (Zhen, Liang \& Tucker, 2010; pers. obs.). They also share antrorsely scabrous reddish bristles and they are confined to the mountainous regions of East and Southeast Asia with considerable overlap in their ranges (Liang \& Tucker, 2010b). Even the position of the unispicate T. alpinum in a largely paucispicate clade and sister to T. scabriculme in ML analyses is coherent because T. alpinum and T. scabriculme are the only species in the genus to possess bristles greater than ten times the length of the nutlet. Most Trichophorum species have bristles that are rarely more than twice the fruit's length and several lack bristles altogether (Liang \& Tucker, 2010b).

With the addition of T. scabriculme to Trichophorum, the genus now consists of 13 species plus a fourteenth, Trichophorum dioicum (Lee \& Oh) J.Jung \& H.K.Choi, whose taxonomy and nomenclature needs to be resolved (see Lee \& Oh, 2006; Lee \& Oh, 2007; Jung \& Choi, 2010). The genus Trichophorum can be separated from other Cyperaceae by its reduced, basal sheathing leaves with ligules, blades much reduced (rarely developed), spikelets solitary or in paucispicate racemes (rarely), flowers surrounded by a perianth of 6 (-14) bristle-like tepals (rarely absent), antrorsely barbed or smooth (rarely), deciduous with fruit containing a Carextype embryo, and with the proximal glume of spikelets sterile (fertile in T. cespitosum), differentiated, and frequently awned.

Species of Trichophorum can be separated into two distinct clades with good support, the T. scabriculme clade described above, which contains the type T. alpinum, and its sister clade, a poorly resolved group of all other Trichophorum plus the genera Cypringlea and Oreobolopsis. Although these two major clades within the Trichophorum clade have received no more than $73-79 \%$ BS support in previous analyses, they present the real possibility that Cypringlea and Oreobolopsis species may need to be transferred to Trichophorum or that new genera will need to be created to maintain generic monophyly. Oreobolopsis species fit well into Trichophorum as they are very similar to species with an inflorescence consisting of a single terminal spikelet, the only remarkable difference being the presence of six broad, membranous tepals in flowers instead of bristles. However, the value of this single perianth character to segregate Oreobolopsis from Trichophorum is questionable (Dhooge, 2005), especially when it appears that glume-like perianth parts are not entirely unknown in species like T. subcapitatum (see Léveillé-Bourret et al., 2014), a close relative of the generic type T. alpinum. Cypringlea also shares several characteristics with Trichophorum such as mostly basal leaves, antrorse to divergent bristle barbs and spikelets with sterile basal glumes, but it possesses well-developed leaves and simple to compound anthelae sometimes consisting of hundreds of spikelets (Strong, 2003; Reznicek \& González-Elizondo, 2008; Léveillé-Bourret et al., 2014). Whether Cypringlea and Oreobolopsis are best treated in Trichophorum will require further analysis, but close relationships among multispicate, paucispicate, and unispicate species are common throughout most of the major 
475

476

477

478

479

480

481

482

483

484

485

486

487

488

489

490

491

492

493

494

495

496

497

498

499

500

501

502

503

504

505

506

507

508

509

510

511

SCC clades, suggesting that reduction and proliferation is a frequent mode of evolution among these lineages (Léveillé-Bourret et al., 2014).

With the removal of Trichophorum scabriculme and Erioscirpus species, the genus Eriophorum s.str. now consists of approximately 18 species (Novoselova, 1994b; Ball \& Wujek, 2002; Léveillé-Bourret \& Starr, in press) with E. transiens an aberrant oddity characterised by spikelets arranged into an anthela of dense, globose heads with branches subtended by extremely long bracts and flowers with bristles fused at the base. This type of inflorescence suggests $E$. transiens is distantly related to Eriophorum and more likely to be allied to elements in the Ficinia Clade as analyses have shown for other recent Scirpus segregates (e.g., Afroscirpoides and Dracoscirpoides; Muasya et al., 2012; García-Madrid et al., 2015). The taxonomy and relationships of E. transiens are currently under study.

Eriophorum can now be separated from Scirpus and all other Cyperaceae by basal and cauline leaves with ligules, spikelets solitary and erect or in subcapitate to pendant anthelae of few $(1-) 2-10(-30)$, typically large spikelets with flowers surrounded by numerous $(10-25)$ smooth, flattened long bristles that are white to rusty-red in colour, and with nutlets containing a Fimbristylis-type embryo. The genus is nested within Scirpus s.str. as currently understood, but further research is required to determine whether the limits of Scirpus are appropriately defined.

\section{Notable morphological differences with previous descriptions and illustrations}

The protologue for Trichophorum scabriculme by Beetle (1946) was based on immature material collected early in the growing season (February). Consequently, no nutlets were present and the elongate bristles that characterise this species were not exsert from the glumes. This immaturity most likely explains why Beetle (1946) gives the number of bristles as six despite 10 to 14 being typical for the species because an accurate count could not be made and he believed the species was a Scirpus. Consequently, Raymond (1957) emended the description of T. scabriculme when he received better material from a second collection of the species by the holotype collector, Alfred Pételot (Raymond, 1955). This description also contains errors, some of which are probably related to the fact that the specimens used by Raymond were too mature. The differences between our observations and Raymond's in bristle length (up to $9 \mathrm{~mm}$ vs. $25 \mathrm{~mm}$ ) and number (up to 24 versus 14) might be explained by the fact that the material at MT ( $A$. Pételot 8635) had already lost many of its nutlets. As we observed efficient wind dispersal of $T$. scabriculme in the field, it is possible that those nutlets with the longest bristles may have already been dispersed by the wind before the plants were collected. Moreover, the unusual bristle numbers reported by Raymond could be due to extrapolation if he believed that many bristles had already been lost due to maturity.

There are other notable differences between our observations and those of Beetle (1946) and Raymond (1957). Whereas they recorded triangular stems for Trichophorum scabriculme, 
512 we observed crescentiform to fusiform culms in cross-section. In addition, neither author 513 mentions anything about the stamens, which is understandable given the problems with specimen 514 maturity noted above. Trichophorum scabriculme has only one stamen, a character apparently 515 unique in Trichophorum, but not entirely uncommon in Cyperaceae (Goetghebeur, 1998).

516 The only illustration of T. scabriculme, which is provided in the Illustrated Flora of 517 Vietnam (Pham, 1993; reproduced in Khôi, 2002), appears to represent an image developed from the composite descriptions of Beetle (1946) and Raymond (1957). None of the plants on specimens available to Phạm in 1993 (Pham, 1993) resemble the illustration, and characters such as bristle number (23) and length (4 $\mathrm{mm})$ appear to be compromises between the conflicting values given in Beetle ( 6 bristles, not exsert from glumes $3-4 \mathrm{~mm}$ long; Beetle, 1946) and Raymond (up to 24 bristles, 8 -9 mm long, glumes 3-4 mm long; Raymond, 1957).

\section{Conservation Status of Trichophorum scabriculme}

525

526

527

528

529

530

531

532

533

534

535

536

537

538

539

540

541

542

543

544

545

546

547

548

Vulnerable (VU) category of IUCN (IUCN, 2012). Prior to this study, Trichophorum scabriculme was known from only two collections ca. $7 \mathrm{~km}$ apart made near $\mathrm{Sa} \mathrm{Pa}$ in Lào Cai Province during the French colonial period over 75 years ago. This is a famous locality for endemism in northern Vietnam that supports a diverse mixture of tropical, subtropical and temperate plants (Raymond, 1959b; Thin \& Harder, 1996; Ford et al., 2015) owing to its mountainous topography which includes mount Phan Xi Păng (Fansipan; 3,143 m), the tallest peak in Indochina.

Here we report the rediscovery of Trichophorum scabriculme at both of the original collection sites, and we extend the number of known populations to nine for 16 total collections of the species. Nonetheless, Trichophorum scabriculme remains a very narrow endemic to the main range of the Hoàng Liên Mountains with just three collections known from outside $\mathrm{Sa} \mathrm{Pa}$ District and two from outside of Lào Cai Province.

Of the nine unique populations documented by specimens or pictures, only five are within protected areas (Hoàng Liên National Park), with several being either directly on the border with the park or near it (Ô Quy Hồ, Tiên Sa Waterfall). Even within the park, all of the sites are heavily influenced by human activity, as they are either primary tourist destinations (Tiên Sa and Silver Waterfalls, Phan Xi Păng) or they are in areas within the park where agriculture and grazing by farm animals is intense (site near Séo Mý Tỷ village). Although $T$. scabriculme occurs in habitats that are typically difficult for animals and people to access (e.g., rock faces, steep streams), they are humid environments. It is thus vulnerable to any hydrological changes that result from the increased use of water for agriculture, fish farming or domestic use, which is common across its narrow range. At one of the Ô Quy Hồ sites where we collected $T$. scabriculme in 2012, significant changes in water flow have since occurred leading to algal buildup and the extirpation of at least one species of Carex collected there before $(C$. 
549 hypolytroides, Ford 1222 et al. , WIN; Fig. 6). Three populations of Trichophorum scabriculme 550 (Bình Lư, Ô Quy Hồ Pass and Văn Bàn) are immediately next to well-travelled roads through 551 mountain passes (QL 4D and QL 279) that could be affected by road widening, especially for 552 any increased traffic due to tourism. This is especially worrisome for populations along QL 4D 553 and on mount Phan Xi Păng given the completion of a cable car to the summit in 2016. In 554 addition, the authors know of only three populations where individuals were $>50-100$ 555 individuals (Ô Quy Hồ Pass, site near Séo Mý Tỷ village, type locality at Tiên Sa Waterfall) and 556 only one herbarium label refers to the plants being "very common" (Than Uyên District) 557 suggesting that the number of mature individuals is limited. We suspect that no more than 4,000 558 individuals currently exist.

559 Although we have significantly increased the number of known collections for the

560

561

562

563

564

565

566

\section{7}

568

569

570

571

572

573

574

575

576

577

578

579

580

581 species and the size of its range, it still possesses an extent of occurrence of only $252.8 \mathrm{~km}^{2}$ over a north/south axis of just $47 \mathrm{~km}$. Owing to its small extent of occurrence $\left(<20,000 \mathrm{~km}^{2}\right)$, limited number of populations $(<10)$, and proximity to intense anthropogenic activity that could lead to the loss of populations or to a significant decline in the number of mature individuals in the near future, Trichophorum scabriculme is considered to be Vulnerable (VU) according to IUCN (2012) criterion B1 (a, b).

\section{Taxonomic treatment}

Key to the species of Trichophorum in Vietnam and southern China (east of Tibet and south of the Chang Jiang or Yangzi River).

1a. Culm fusiform to crescentiform in cross-section, with one sharp edge scabrous to base; bracts with long scabrous awns 4-10(-20) mm long; perianth bristles long exserted from glumes at maturity, forming a red cottony mass .Trichophorum scabriculme

1b. Culm terete to obtusely trigonous, smooth or scabrous only near apex; bracts with awns 0 $5 \mathrm{~mm}$ long or absent; perianth bristles not much exserted from glumes or absent

2a. Inflorescence racemose to unispicate; perianth bristles present; all glumes in spikelets acute Trichophorum subcapitatum agg.

2b. Inflorescence strictly unispicate; perianth absent; proximal glume in spikelets mucronate, others obtuse. 
582 Trichophorum scabriculme (Beetle) J. R. Starr, Lév.-Bourret \& B. A. Ford comb. nov. Type: 583 Indo-chine (Vietnam), Tonkin, Chapa. Parois siliceuses du ravin à la Cascade, vers $1200 \mathrm{~m}$. 584 Février 1931, A. Pételot 6128 (holotype, GH!); isotypes P!, VNM (Photo!))

585 Basionym: Scirpus scabriculmis Beetle, American Journal of Botany 33: 665-666 (1946).

586 Eriophorum scabriculme (Beetle) Raymond (1957: 147).

587

588

589

590

591

592

593

594

595

596

597

598

599

600

601

602

603

604

605

606

607

608

609

610

611

612

613

614

615

616

617

618

619

Description. - Perennial herb, 10-60 cm tall, forming dense tufts of up to hundreds of culms.

Roots smooth, faded yellow-brown to grey-brown, the central white strand surrounded by a thin ring of brown tissue and free from the rind. Aerial vegetative parts dark green. Culms pendant, crescentiform to fusiform in cross-section with a rounded edge and a sharp edge, $0.3-0.6 \mathrm{~mm}$ wide near base, antrorsely scabrous on the sharp edge with needle-like hyaline teeth 0.2 $0.3 \mathrm{~mm}$ long, the sheath-clad base $1-1.6 \mathrm{~mm}$ wide including sheaths. Leaves all basal, but blades appearing cauline due to elongate sheaths. Distalmost leaf sheath $20-60 \mathrm{~mm}$ long, $0.7-$ $1 \mathrm{~mm}$ wide at apex; inner bands very long, white-hyaline to brownish, apex somewhat inflated and indurated, white-hyaline with generally abundant red dots, at a $27-47^{\circ}$ angle to the transverse plane of the culm; membranous ligule apparent as a projection of the leaf-sheath beyond leaf blade insertion, $0.2-0.4 \mathrm{~mm}$ long. Distalmost leaf blade $19-41 \times 0.3-0.5 \mathrm{~mm}$, involute-filiform, crescentiform in section, antrorsely scabrous with needle-like teeth on the margins from base to apex. Inflorescence unispicate or a very short raceme of $2-3$ spikelets. Basal bracts sheathless, scale-like, with body $0.7-2 \times 0.9-1.7 \mathrm{~mm}$, with awn $4-10(-20) \times$ $0.14-0.24 \mathrm{~mm}$, flat, antrorsely scabrous on margins with needle-like barbs, rounded at the apex. Inflorescence always with $1-2$ bracts at base. Spikelets narrowly elliptic when immature, 5-9 $\times 1.4-3 \mathrm{~mm}$, becoming elliptic to obovate, the initially appressed glumes spreading at fructification; rachilla $0.4-0.7 \mathrm{~mm}$ wide including protruding receptacles, becoming dark-red with age, middle internodes $0.18-0.26 \mathrm{~mm}$, receptacles upwardly open and protruding $0.1-$ $0.2 \mathrm{~mm}$ from the rachilla axis; lateral spikelet prophyll empty, persistent, ovate to orbicular, ca. $1.3-2.2 \times 0.9-1.5 \mathrm{~mm}$, obtuse to bidentate at apex, completely encircling the pedicel at base but not sheathing, ca. 0.6 - 0.7 times as long as proximal glume, with 2 (rarely 3 ) major ribs reaching the teeth and several obscure red veins becoming indistinct below the middle, with several marginal barbules at the apex. Glumes ca. 14-18, deciduous, proximal glume sterile and sometimes awned, remainder all fertile and acute to shortly mucronate, proximal $2-3$ smaller than the following, middle glumes triangular, $3-3.5 \times 1.4-2 \mathrm{~mm}, 1.7-2$ times as long as wide, mucronate to acute at apex, reddish-brown, chartaceous, margin undifferentiated; broad midrib pale, with a central prominent nerve reaching the apex; margins sometimes minutely barbed near the apex; glume wings extending around the flowers below their insertion point. Flowers bisexual, spiro-tristichously inserted; perianth bristles ca. 10-14, flat, pale tawnybrown to pale reddish-brown, sometimes with abundant red lines, to $25 \mathrm{~mm}$ long, much longer than nutlet, proximally smooth, but with minute antrorse barbs distally on margins and at apex, 
620 barbs hyaline and sharp; stamen 1, placed abaxially, the largest mature anthers ca. $1.5-1.6 \mathrm{~mm}$

621 long, with very short acute red apiculum, filament to ca. 1.5-3.8 mm long; style ca. 2.9-4 mm, 622 red, 3-branched, the branches ca. 1.4-2.5 $\mathrm{mm}$ with abundant large papillae as long as wide.

623 Nutlets $1.7-2.2 \mathrm{~mm}$ long, reddish-brown, surface minutely granular at maturity from silica624 body projections; body fusiform, $1.5-1.9 \times 0.4-0.7 \mathrm{~mm}, 2.5-4$ times as long as wide, ca.

$625 \quad 0.3-0.4 \mathrm{~mm}$ thick, plano-convex in section with a thickness/width ratio of ca. 0.5-0.7; beak 626 clearly defined, 0.1-0.3 mm long including dark style remnant. Embryo narrowly turbinate in 627 outline, with a basal root cap and lateral germ pore (Carex-type).

\section{Recognition}

630 The type was originally identified as Scirpus subcapitatus Thwaites \& Hook. (=Trichophorum 631 subcapitatum (Thwaites \& Hook.) D.A. Simpson), but it differs markedly from this species and 632 all other southern Chinese and Vietnamese Trichophorum by culms scabrous on one edge from 633 their base to apex versus culms smooth or scabrous apically only; by bracts with long scabrous awns (4-10 $\mathrm{mm}$ long) versus bracts lacking awns or shorter ( $0-5 \mathrm{~mm}$ long), and by fruits subtended by long bristles exsert from glumes versus bristles only slightly exceeding glume length or entirely lacking, amongst other characters. Like all Trichophorum species, it cannot be confused with Eriophorum or Scirpus because all its leaves are basal, and with highly reduced blades (except in T. planifolium), whereas species of Eriophorum and Scirpus have both welldeveloped basal and cauline leaves, with few exceptions.

Trichophorum scabriculme has also been provisionally determined as a Carex (D.K. Harder et al. 6826), a Fimbristylis (A. Pételot 5498, Fimbristylis cf. pauciflora; Fimbristylis sp. for all specimens in Hoàng Liên National Park Herbarium) and an Eleocharis (N.T. Hiep, P.H. Hoang \& L. Averyanov 2846). This is understandable as it can superficially resemble singlespiked Carex species, and Fimbristylis and Eleocharis species with inflorescences composed of single spikelets. Carex can be distinguished from T. scabriculme by unisexual flowers and the presence of a perigynium; Eleocharis by distinct, thickened and persistent style-bases (tubercles) and eligulate leaves, and Fimbristylis by the absence of bristles and a deciduous style. It could also be possible to confuse T. scabriculme with Isolepis species that have just one or a few spikelets, but like Fimbristylis species, they lack bristles.

650

\section{Distribution} District and Lai Châu Province, from Tam Đường District south to Tân Uyên District. 
655

656

657

658

659

660

661

662

663

664

665

666

667

668

669

670

671

672

673

674

675

676

677

678

679

680

681

682

683

684

685

686

687

688

689

690

691

692

693

\section{Specimens Examined}

Because of the strong cultural influence of China, western travelers and trade, French colonialism, and the recent tumultuous period leading to full Vietnamese independence, place names and the political divisions of Vietnam have frequently changed. This means that multiple names and spellings typically exist for the same locality (McLeod and Nguyen, 2001; Woodside, 2006). For example, the modern tourist town of $\mathrm{Sa} \mathrm{Pa}$ is spelt in most guidebooks as Sapa, whereas the French referred to it as Chapa or Cha-pa, and on the 1966 United States military map for Lào Kay (sheet 5753 I, series L7014; Lào Cai today), it is spelt Cha Pa. The French called the great pass west of $\mathrm{Sa} \mathrm{Pa}$ that reaches $2000 \mathrm{~m}$ Lö qui Hô (with many variants), but today it is formally known as Ô Quy Hồ and informally as Trạm Tôn, a name that refers to the fact the old ranger station had a metal roof over 20 years ago. Even the Vietnamese spelling of this common locality differs with the most frequent being Ô Quy Hồ whilst an administrative atlas of Vietnam (2008) writes it as Ô Quí Hồ. We know of at least seven different spellings for mount Phan Xi Păng, the highest mountain in Indochina. Moreover, because Vietnamese is a tonal language, but has a Latin alphabet, western herbarium labels almost always lack the diacritical marks that are the key to the pronunciation and meaning of words. In order to avoid future confusion, every effort was made to use the most common modern Vietnamese spelling with diacritical marks, even if this was not done on the label. Names in parentheses represent either common names used for the same locality (e.g., Tram Tôn or Ô Quy Hồ Pass), translations of the Vietnamese (e.g., Thác Bạc or "Silver Waterfall"), or a modern rendition of colonial names (e.g., Sa Pa for Chapa). Unless indicated, the latitude and longitudes given for specimens are accurate to $<1 \mathrm{~km}$ if not taken by GPS. The acronym "hlnph" stands for the Hoàng Liên National Park Herbarium, which contains approximately 8,000 well-curated specimens of the flora of the park (Vu Ahn Tai, Pers. Comm.), but is not listed in Index Herbariorum.

VIẸT NAM. Lào Cai Province, Sa Pa District, Hoàng Liên National Park, Tram Tôn (Ô Quy Hồ Pass) (22 21' 18.93" N, 103 46' 27.25" E), 13 September 2005, Trinh Dinh Hung HL-165 (hlnph); . Lào Cai Province, Sa Pa District, Hoàng Liên National Park, Tram Tôn (Ô Quy Hồ Pass) (22 21' 18.93" N, $103^{\circ} 46^{\prime} 27.25^{\prime \prime}$ E), 18 July 2005, Trinh Dinh Hung 164 (hlnph); Lào Cai Province, Sa Pa District, Hoàng Liên National Park, Tram Tôn (Ô Quy Hồ Pass) $\left(22^{\circ} 21^{\prime}\right.$ 18.93" N, $103^{\circ} 46^{\prime} 27.25^{\prime \prime}$ E), 13 September 2005, Trinh Dinh Hung s.n. (hlnph); Lào Cai Province, Sa Pa District, Hoàng Liên National Park, Tram Tôn (Ô Quy Hồ Pass) (22 21' 18.93" N, $103^{\circ}$ 46' 27.25" E), 17 September 2005, Trinh Dinh Hung HL-161 (hlnph); Lào Cai Province, Sa Pa District, Hoàng Liên National Park, Sín Chải (22 $25^{\prime} 42.18^{\prime \prime}$ N, $103^{\circ} 47^{\prime} 54.85^{\prime \prime}$ E), Tran Van Tu TK050410 — 50, 4 April 2005 (hlnph). Lào Cai Province, Sa Pa District, Hoàng Liên National Park, Sín Chải , Vu Anh Tai TK050410-30, 4 April 2005 (hlnph). Lào Cai Province, Sa Pa District, Bản Khoang (22 25' 42.18" N, $103^{\circ} 47^{\prime}$ 54.85" E), Dang Quyet Chien s.n., 17 June 2005 (hlnph). Lào Cai, Văn Bàn District, Nậm Xé Commune (Municipality on label).

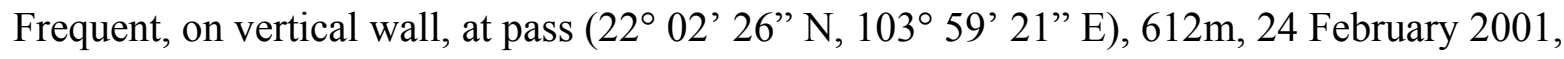


694 D.K. Harder et al. 6826 (HN, MO); Lào Cai Province, Sa Pa District, Ô Quy Hồ Commune,

695

696

697

698

699

700

701

702

703

704

705

706

707

708

709

710

711

712

713

714

715

716

717

718

719

720

721

722

723

724

725

726

727

728

729

730

731

732
Hoàng Liên National Park, on road to Lai Châu (QL 4D), ca. $10 \mathrm{~km} \mathrm{~W}$ of Sa Pa, ca. $100 \mathrm{~m} \mathrm{~W}$ of Thác Bạc (Silver Waterfall). Open rock face adjacent to waterfall (22 $21^{\circ} 33.32^{\prime \prime} \mathrm{N}, 103^{\circ} 46^{\prime}$ 39.48", GPS), $1831 \mathrm{~m}$ (GPS), $1770 \mathrm{~m}$ (barometric altimeter), 10 April 2012, B. Ford 1225, J. Starr and J. Regalado (WIN). Lào Cai Province, Sa Pa District, Hoàng Liên National Park, Ô Quy Hồ Commune, on road to Lai Chau (QL 4D), ca. $10 \mathrm{~km} \mathrm{~W}$ of Sa Pa, ca. $300 \mathrm{~m}$ W of Thác Bạc (Silver Waterfall). Rock fissures and faces with seepage, adjacent to and at bottom of waterfall, plants growing from a moss substrate $\left(22^{\circ} 21^{\prime} 19.2^{\prime \prime} \mathrm{N}, 103^{\circ} 46^{\prime} 25.8^{\prime \prime} \mathrm{E}\right.$, GPS [WGS 84]), $1850 \mathrm{~m}$ (barometric altimeter), 10 April 2012, B. Ford 1227, J. Starr and J. Regalado (WIN). Lào Cai Province, Sa Pa District, Tả Van Commune, Hoàng Liên National Park, gravel road to Séo Mý Tỷ village. Growing in moss pockets on narrow rock ledges and fissures along fast moving stream (22 $15^{\circ} 37.9^{\prime}$ N, $103^{\circ} 53^{\prime 24.2}$ " E, GPS [WGS 84]), 1716 m (GPS), 15 April 2012, B. Ford 1256, J. Starr, J. Regalado, Vu Anh Tai, and Nguyen Kim Thanh (WIN). Lào Cai Province, Sa Pa District, Hoàng Liên National Park, Tram Tôn Trail (main trail) to summit of Mount Phan Xi Păng (Fansipan) between "2900 Pass" and summit, open, NE facing moist granitic rock face with moss covered ledges and pockets $\left(22^{\circ} 18^{\prime} 26.9^{\prime \prime} \mathrm{N}, 103^{\circ} 46^{\prime} 17.9^{\prime}\right.$ 'E, GPS [WGS 84]), $2878 \mathrm{~m}$ (GPS), $2760 \mathrm{~m}$ (altimeter), 21 April 2015 , B. Ford 15080, J. Starr, É. Léveillé-Bourret, Nguyen Thi Kim Thanh, Vũ Anh Tài, and S. Ford (WIN). Lào Cai Province, Sa Pa District, Hoàng Liên National Park, Cát Cát, trail along suối Vàng (Gold Stream), in the vicinity of Cát Cát Waterfall (Thác Tiên Sa or "La Cascade" in French), right bank of suối Vàng in fissures of moist granitic rock faces above and along stream $\left(22^{\circ} 19^{\prime} 18.8^{\prime} \mathrm{N}, 103^{\circ} 49^{\prime} 34.4^{\prime}\right.$ 'E, GPS [WGS 84]), elevation 1245m (GPS), 1150 m (altimeter), 24 April 2015, B. Ford 15089, J. Starr, É. Léveillé-Bourret, Nguyen Thi Kim Thanh, Vũ Anh Tài, and S. Ford (WIN); Tonkin (Northern Vietnam): Chapa (Sa Pa, Lào Cai Province). Parois siliceuses du ravin à la Cascade (22 ${ }^{\circ} 19^{\prime} 38.57^{\prime \prime} \mathrm{N}, 103^{\circ} 50^{\prime} 04.28^{\prime \prime} \mathrm{N}$, visited), vers $1200 \mathrm{~m}$. février 1931, A. Pételot 6128 (P, GH; VNM, photo!); Tonkin: Chapa, Col de Lö qui Hô (Ô Quy Hồ Pass), fissures des rochers calcaires très ensoleillés, vers 2200 mètres (22 21' 12.28" N, $\left.103^{\circ} 46^{\prime} 26.64 " \mathrm{E}\right)$, avril 1944, A. Pételot 8635 (MT, L); Tonkin: Chapa. Sur rochers siliceux au milieu d'un torrent près du gué Ysault, vers 1300m, environs de Chapa, février 1931, Pételot 5498 (P) (locality unknown). Lai Châu Province, Tam Đường District, Bình Lư Commune, on road to Bình Lư (QL 4D), ca. 11.4 km W of Sa Pa by air or $22 \mathrm{~km}$ by road, SE facing weeping granitic rock face along highway, soil $\mathrm{pH}$ 6.7 (222 21'31.2”N, 103 44' 02.5'E, GPS[WGS 84]), 1546 m (GPS), 18 April 2015, B. Ford 15053, J. Starr, É. Léveillé-Bourret, Nguyen Thi Kim Thanh, Vũ Anh Tài, and S. Ford (WIN); (Lào Cai Province on label), Than Uyên District (now Tân Uyên District), Hố Mít Commune (Municipality on label). Lithophytic sedge on open wet vertical bluffs - very common $\left(22^{\circ} 06^{\prime} \mathrm{N}\right.$ $103^{\circ} 52^{\prime}$ E; mapped as $22^{\circ} 6^{\prime} 49.5 \mathrm{~N}, 103^{\circ} 55^{\prime} 33.4^{\prime \prime}$ E based on label description, but $>1 \mathrm{~km}$ inaccuracy), 1700-2200 m, 21 May 1999, N.T. Hiep, P.H. Hoang \& L. Averyanov 2846 (MO).

\section{Habitat}

Peer] reviewing PDF | (2019:04:36328:1:1:NEW 17 Jul 2019) 
733 Mountains (612 $\mathrm{m}$ to $2878 \mathrm{~m}$ ) in full sun on vertical rock walls and road cuts, along steep

734 cascading streams and on the edges and foot of waterfalls where moisture is present. Plants

735 typically grow within a moss substrate. Carex hypolytroides and Scirpus ternatanus Reinwardt

736 ex Miquel were seen at all localities near Sa Pa where this species was collected (Ford et al.

$7371225,1227,1256$ ).

738

739

\section{Conservation Status}

740 Vulnerable (VU) category of IUCN (2012) based on criterion B1 (a, b). Only nine populations 741 are known $(<10)$ and the extent of occurrence is $252.8 \mathrm{~km}^{2}\left(<20,000 \mathrm{~km}^{2}\right)$. Owing to intense

742 anthropogenic activity near most populations (roads, agriculture, fish farming, tourism), there is

743 reason to believe that subpopulations could be lost or a significant decline in the number of

744 mature individuals could occur in the near future.

\section{Etymology}

747

748

749

750

751

752

753

754

755

756

757

758

759

760

761

762

763

764

765

766
The epithet scabriculme combines the Latin word for rough or scabrous (scabri-) with the Latin for culm (culmus) in reference to the culms of T. scabriculme that are scabrous from their base to their apex, a character that is unique in Trichophorum.

\section{Notes}

In addition to the localities noted above, plants were also seen at two additional localities in the $\mathrm{Sa} \mathrm{Pa}$ District of Lào Cai Province. As these plants were either too mature or too immature to make adequate herbarium specimens, they were not collected, but georeferenced photographs were taken to document their existence. In the interests of conservation, these localities are briefly described as follows (localities are very close to collections cited above): (1) Immature plant on steep edge of Thác Bạc (Silver Waterfall) (22 21' 44.69" N, 103 46' 38.15" E), 10 April 2012, 1733 m (GPS); (2) large population of overly mature plants along south facing rock wall of the road (QL 4D) to Ô Quy Hồ Pass (22 21' 21.67" N, $103^{\circ} 46^{\prime} 33.07^{\prime \prime}$ E), 10 April $2012,1882 \mathrm{~m}$ (GPS). Note that these two localities demonstrate how the maturity of specimens can vary widely over short distances if there are significant differences in hydrology and sun exposure.

Beetle's (1946) translation of the French label data on the holotype (Pételot 6128) "IndoChina, Chape, rocks of ravine, Feb. 1931" is incomplete and does not help with determining the type locality. The label is translated here as "Indochina, Tonkin, Chapa. Siliceous walls of the ravine at the Cascade, around 1200m, February 1931”. During the French Colonial period, "La 
767 Cascade" was a popular tourist attraction near Sa Pa (Chapa) that was described, mapped and

768

769

770

771

772

773

774

775

776

777

778

779

780

781

782

783

784

785

786

787

788

789

790

791

792

793

794

795

796

797

798

799

800

801

802

pictured in tourist guides (Anonymous, 1924; Anonymous, 1932). "La Cascade" is here identified as Tiên Sa Waterfall (N22¹9'38.57", E10350'04.28") near Cát Cát village, which is approximately $2 \mathrm{~km}$ by road from $\mathrm{Sa} \mathrm{Pa}$ and continues to be a popular tourist attraction today. "La Cascade" can be definitively identified as the type locality thanks to the presence of a hydroelectric power station constructed by the French in 1925 that is mentioned in one guide (Anonymous, 1932) and still exists at the site to this day. Moreover, the elevation of the site (ca. $1237 \mathrm{~m}$ ) is consistent with the holotype's label (around $1200 \mathrm{~m}$ ). When we visited the site in 2015, Trichophorum scabriculme could still be seen growing on the rock faces opposite the main terrace for tourists to view the waterfalls. From this position, a population consisting of thousands of plants could be seen on a rock face approximately $200 \mathrm{~m}$ upstream and $30 \mathrm{~m}$ above the right bank of the suối Vàng. This is the largest population known to us. The name of the modern village of Cát Cát has no meaning in Vietnamese and is mostly likely derived from the French word "Cascade" for the waterfalls at this locality.

\section{Conclusions}

Although Trichophorum scabriculme possesses a unique combination of characters within sedges, DNA data, morphology and embryology strongly support its position within the Scirpo-Caricoid Clade including its placement within the genus Trichophorum. Trichophorum now consists of 14 species, but it is likely that future studies will conclude that its limits include species of Cypringlea and Oreobolopsis as well. Eriophorum s.str. now consists of approximately 18 species, but it is likely that future studies will find that the aberrant $E$. transiens is best aligned with elements in the Ficinia Clade. Eriophorum is nested in Scirpus s.str. but further research is required to determine whether the limits of Scirpus are appropriately defined.

Despite discovering seven new populations and extending its range westward to Lai Châu Province and southward in Lào Cai Province by more than $47 \mathrm{~km}$, the conservation status of Trichophorum scabriculme in Vietnam is Vulnerable (VU). Only 56\% of populations are found in protected areas and intense anthropogenic activity continues to threaten the existence of this unique sedge species.

\section{Acknowledgements}

We are very thankful to James C. Solomon (MO), Carine Denjean (NCY), Mark T. Strong (US), Nicolien Sol (L), Robert Vogt (B), Debra Trock (CAS), Andrew S. Doran (UC), Hans V. Hansen (C), Adele Smith (E), John Hunnex (BM), and Dang Van Son (VNM) for searching their respective herbaria for possible isotypes. We are also grateful to Dr. Jean

Peer] reviewing PDF | (2019:04:36328:1:1:NEW 17 Jul 2019) 
803 Michaud (Université Laval) for highlighting the connection between the modern name Cát Cát

804 and the French "La Cascade". We would also like to thank Bobbi Angell for illustrating

805 Trichophorum scabriculme, Colin Chapman for embryo micrographs (University of Ottawa), and 806 Khaled Himmat (University of Ottawa) for preparing the distribution map.

807

808

\section{References}

809

810

811

812

813

814

815

816

817

818

819

820

821

822

823

824

825

826

827

828

829

830

831

832

833

834

835

836

837

838

839

840

Alexander PJ, Rajanikanth G, Bacon CD, Bailey CD. 2007. Recovery of plant DNA using a reciprocating saw and silica-based columns. Molecular Ecology Notes 7:5-9.

Anonymous. 1924. Protectorat du Tonkin, Province de Lao-Kay, Livret-guide de la station d'altitude de Chapa. Hanoi: Syndicat d'Initiative de Chapa.

Anonymous. 1932. Indochine du nord: Tonkin, Annam, Laos, Yunnan, Fouang-Tcheou Wan (cartes et plans). Paris: Société d'éditions géographiques.

Bachman S, Moat J, Hill AW, de Torre J, Scott B. 2011. Supporting Red List threat assessments with GeoCAT: geospatial conservation assessment tool. ZooKeys:117-126. DOI 10.3897/zookeys.150.2109

Ball PW, Wujek DE. 2002. Eriophorum Linnaeus. In: Flora of North America Editorial Committee, ed. Flora of North America, north of Mexico. Oxford: Oxford University Press, 21-27.

Beetle AA. 1946. Studies in the genus Scirpus L. VIII. Notes on its taxonomy, phylogeny, and distribution. American Journal of Botany 33:660-666.

Bruhl JJ. 1995. Sedge genera of the world: relationships and a new classification of the Cyperaceae. Australian Systematic Botany 8:125-305.

Clarke CB. 1908. New genera and species of Cyperaceae. Bulletin of miscellaneous information Additional Series 8:1-196.

DeBry RW, Olmstead RG. 2000. A simulation study of reduced tree-search effort in bootstrap resampling analysis. Systematic Biology 49:171-179.

Dhooge S. 2005. Systematic revision and phylogeny of the Andean scirpoids (Cyperaceae, Scirpeae) M.Sc. Universiteit Gent.

Dhooge S, Goetghebeur P, Muasya AM. 2003. Zameioscirpus, a new genus of Cyperaceae from South America. Plant Systematics and Evolution 243:73 - 84

Egorova T. 2004. Genus Scirpus L. (Cyperaceae) in Flora Eurasiae (in Russian). Novosti Sistematiki Visshih Rasteniy 36:40-79.

Felsenstein J. 1985. Confidence limits on phylogenies: an approach using the bootstrap. Evolution 39:783-791.

Ford BA, Vu AT, Nguyen KT, Starr JR. 2015. Luzula effusa var. chinensis (Juncaceae): the first record for the wood-rush genus in Vietnam. Phytotaxa 204:116-122. DOI 10.11646/phytotaxa.204.2.2

Fridriksson S. 1982. Life develops on Surtsey. Endeavour 6:100-107. 
841 Fu L. 2009. Higher Plants of China. Beijing: Science Press.

842

843

844

845

846

847

848

849

850

851

852

853

854

855

856

857

858

859

860

861

862

863

864

865

866

867

868

869

870

871

872

873

874

875

876

877

878

879

García-Madrid AS, Muasya AM, Álvarez I, Cantó P, Molina JA. 2015. Towards resolving phylogenetic relationships in the Ficinia clade and description of the new genus Afroscirpoides (Cyperaceae: Cypereae). Taxon 64:688-702. DOI 10.12705/644.2

Gilmour CN, Starr JR, Naczi RFC. 2013. Calliscirpus, a new genus for two narrow endemics of the California Floristic Province, C. criniger and C. brachythrix sp. nov. (Cyperaceae). Kew Bulletin 68:85-105.

Goetghebeur P. 1986. Genera Cyperacearum: Een bijdrage tot de kennis van de morfologie, systematiek en fylogenese van de Cyperaceae - genera Ph.D. Rijksuniversiteit Gent.

Goetghebeur P. 1998. Cyperaceae. In: Kubitzki K, ed. The families and genera of vascular plants IV, flowering plants - monocotyledons, Alismatanae and Commelinanae (except Gramineae). Berlin: Springer, 141-190.

Hoshino T, Masaki T, Nishimoto M. 2011. Illustrated sedges of Japan. Tokyo: Heibonsha Ltd. IUCN. 2012. IUCN Red List Categories and Criteria: Version 3.1. Gland, Switzerland: IUCN.

IUCN, UNEP. 2014. The World Database on Protected Areas (WDPA). Available at www.protectedplanet.net.

Jung J, Choi H-K. 2010. A new endemic species in Trichophorum (Cyperaceae) from South Korea. Novon 20:289-291.

Katoh K, Standley DM. 2013. MAFFT multiple sequence alignment software version 7: improvements in performance and usability. Molecular Biology and Evolution 30:772780.

Kern JH. 1956. Florae Malesianae Praecursores XIII: Notes on Malaysian and some S. E. Asian Cyperaceae IV. Reinwardtia 4:89-97.

Kern JH. 1974. Cyperaceae. Flora Malesiana 7:435-753.

Khôi NK. 2002. Họ Cói - Cyperaceae Juss. Thục vật chí Việt Nam (Flora of Vietnam). Hanoi: Science and Technics Publishing House, 1-570.

Koyama T. 1958. Taxonomic study of the genus Scirpus Linné. Journal of the Faculty of Science, University of Tokyo, Section 3, Botany 7:271-366

Lanfear R, Calcott B, Ho S, Guindon S. 2012. PartitionFinder: combined selection of partitioning schemes and substitution models for phylogenetic analyses. Molecular Biology and Evolution 29:1695-1701.

Larridon I, Bauters K, Reynders M, Huygh W, Muasya AM, Simpson DA, Goetghebeur P. 2013. Towards a new classification of the giant paraphyletic genus Cyperus (Cyperaceae): phylogenetic relationships and generic delimitation in C4 Cyperus. Botanical Journal of the Linnean Society 172:106-126. DOI 10.1111/boj.12020

Lee YN, Oh YC. 2006. A new genus and a new species of Cyperaceae. Bulletin of Korea Plant Research 6:24-30.

Lee YN, Oh YC. 2007. A comparative study of Neoscirpus dioicus (Y.Lee \& Y.Oh) Y.Lee \& Y.Oh and Scirpus caespitosus Linné. Bulletin of Korea Plant Research 7:23-26.

Peerj reviewing PDF | (2019:04:36328:1:1:NEW 17 Jul 2019) 
880

881

882

883

884

885

886

887

888

889

890

891

892

893

894

895

896

897

898

899

900

901

902

903

904

905

906

907

908

909

910

911

912

913

914

915

916

917

918

919

Léveillé-Bourret É, Donadío S, Gilmour CN, Starr JR. 2015. Rhodoscirpus (Cyperaceae: Scirpeae), a new South American sedge genus supported by molecular, morphological, anatomical and embryological data. Taxon 64:931-944. DOI 10.12705/645.4

Léveillé-Bourret É, Gilmour CN, Starr JR, Naczi RFC, Spalink D, Sytsma KJ. 2014. Searching for the sister to sedges (Carex): resolving relationships within the CariceaeDulichieae-Scirpeae clade (Cyperaceae). Botanical Journal of the Linnean Society 176:121.

Léveillé-Bourret É, Starr JR. in press. Molecular and morphological data reveal three new tribes within the Scirpo-Caricoid Clade (Cyperoideae, Cyperaceae). Taxon.

Léveillé-Bourret E, Starr JR, Ford BA. 2018. Why are there so many sedges? Sumatroscirpeae, a missing piece in the evolutionary puzzle of the giant genus Carex (Cyperaceae). Molecular Phylogenetics and Evolution 119:93-104. DOI 10.1016/j.ympev.2017.10.025

Léveillé-Bourret É, Starr JR, Ford BA, Lemmon EM, Lemmon AR. 2018. Resolving rapid radiations within angiosperm families using anchored phylogenomics. Systematic Biology 67:94-112.

Liang S, Tucker-Drob EM, Simpson DA. 2010. 5. Eriophorum Linnaeus, Sp. P1. 1: 52.1753. Flora of China 23:174-176.

Liang S, Tucker GC. 2010a. 4. Scirpus Linnaeus, Sp. P1. 1: 47. 1753, nom. cons. Flora of China 23:171-174.

Liang S, Tucker GC. 2010b. 6. Trichophorum Persoon, Syn. P1. 1: 69. 1805, nom. cons. Flora of China 23:176-178.

Linnaeus C. 1753. Species Plantarum Exhibitentes Plantas Rite Cognitas ad Genera Relatas, cum Differentiis Specificis, Nominibus Trivialibus, Synonymis Selectis, et Locis Natalibus, Secundum Systema Sexuale Digestas. Stockholm, Sweden: Laurentius Salvius.

Muasya AM, Reynder M, Goetghebeur P, Simpson DA, Vrijdaghs A. 2012. Dracoscirpoides (Cyperaceae) - A new genus from Southern Africa, its taxonomy and floral ontogeny. South African Journal of Botany 78:104-115.

Muasya AM, Simpson D, Verboom G, Goetghebeur P, Naczi RC, Chase M, Smets E. 2009. Phylogeny of Cyperaceae based on DNA sequence data: current progress and future prospects. The Botanical Review 75:2-21. DOI 10.1007/s12229-008-9019-3

Muasya AM, Simpson DA, Chase MW, Culham A. 1998. An assessment of suprageneric phylogeny in Cyperaceae using rbcL DNA sequences. Plant Systematics and Evolution 211:257-271.

Muasya AM, Simpson DA, Chase MW, Culham A. 2000. Phylogenetic relationships within the heterogeneous Scirpus s. lat. (Cyperaceae) inferred from $r b c L$ and $t r n L-F$ sequence data. In: Wilson KL, and Morrison DA, eds. Monocots: Systematics and Evolution. Melbourne: CSIRO Publishing, 610-614.

Noltie HJ. 1994. Flora of Bhutan including a record of plants from Sikkim and Darjeeling, volume 3, part 1: Royal Botanic Garden, Edinburgh. 
920

921

922

923

924

925

926

927

928

929

930

931

932

933

934

935

936

937

938

939

940

941

942

943

944

945

946

947

948

949

950

951

952

953

954

955

956

957

958

959

Novoselova MS. 1994a. The system of the genus Eriophorum (Cyperaceae). I. Subgenera Erioscirpus, Eriophoropsis, Phyllanthela. Botanicheskiy Zhurnal 79:77-89.

Novoselova MS. 1994b. The system of the genus Eriophorum (Cyperaceae). II. Subgenerus Eriophorum. Botanicheskiy Zhurnal 79:66-75.

Oteng-Yeboah AA. 1974. Four new genera in Cyperaceae-Cyperoideae. Notes from the Royal Botanic Garden Edinburgh 33:307-310.

Phạm HH. 1993. Cây cỏ Việt Nam (an illustrated flora of Vietnam), volume 3, part 2. Montréal.

Raymond M. 1955. Cypéracées d'Indo-Chine. I. Naturaliste Canadien 82:145-165.

Raymond M. 1957. Some new critical Scirpus from Indo-China. Mémoires du Jardin Botanique de Montréal 48:111-149.

Raymond M. 1959a. Additional notes on some S. E. Asiatic Scirpus. Le Naturaliste Canadien $86: 225-242$.

Raymond M. 1959b. Carices Indochinenses necnon Siamenses. Mémoires du Jardin Botanique de Montréal 53:1-125.

Reznicek AA, González-Elizondo MS. 2008. Cypringlea (Cyperaceae) revisited, a new combination and status. Acta Botanica Mexicana 83:1-11.

Salmenkallio M, Kukkonen I. 1989. (930) Proposal to conserve 466a Trichophorum (Cyperaceae) with a conserved type. Taxon 38:313-316.

Schuyler AE. 1971. Scanning electron microscopy of achene epidermis in species of Scirpus (Cyperaceae) and related genera. Proceedings of the Academy of Natural Sciences of Philadelphia 123:29-52.

Semmouri I, Bauters K, Léveillé-Bourret É, Starr JR, Goetghebeur P, Larridon I. 2019. Phylogeny and systematics of Cyperaceae, the evolution and importance of embryo morphology. The Botanical Review 85:1-39. aDOI 10.1007/s12229-018-9202-0

Simonis P, Rattal M, Oualim el M, Mouhse A, Vigneron JP. 2014. Radiative contribution to thermal conductance in animal furs and other woolly insulators. Optics Express 22:19401951. DOI 10.1364/OE.22.001940

Simpson DA. 1998. A new species, new combination and new records of Cyperaceae from Thailand. Kew Bulletin 53:225-229.

Small E, Cayouette J. 2016. 50. Sedges - the key sustainable resource for Arctic biodiversity. Biodiversity:1-10. DOI 10.1080/14888386.2016.1164624

Stamatakis A. 2014. RAxML version 8: a tool for phylogenetic analysis and post-analysis of large phylogenies. Bioinformatics 30:1312-1313.

Starr JR, Harris SA, Simpson DA. 2004. Phylogeny of the unispicate taxa in Cyperaceae tribe Cariceae I: generic relationships and evolutionary scenarios. Systematic Botany 29:528544.

Starr JR, Janzen FH, Ford BA. 2015. Three new, early diverging Carex (Cariceae, Cyperaceae) lineages from East and Southeast Asia with important evolutionary and biogeographic implications. Molecular Phylogenetics and Evolution 88:105-120. DOI 10.1016/j.ympev.2015.04.001 
960 Starr JR, Naczi RFC, Chouinard BN. 2009. Plant DNA barcodes and species resolution in sedges (Carex, Cyperaceae). Molecular Ecology Resources 9 (Suppl. 1):151-163.

962 Strong MT. 2003. Cypringlea, a new genus of Cyperaceae from Mexico. Novon 13:123-132.

963 Swofford DL. 2003. PAUP*. Phylogenetic Analysis Using Parsimony (*and Other Methods).

964 Version 4. Novon. Sunderland, Massachusetts, USA: Sinauer Associates.

965 Thin NN, Harder DK. 1996. Diversity of the flora of Fan si Pan, the highest mountain in

966 Vietnam. Annals of the Missouri Botanical Garden 83:404-408.

967 van der Veken P. 1965. Contribution à l'embryographie systématique des Cyperaceae-

968 Cyperoideae. Bulletin du Jardin Botanique de l'État à Bruxelles 35:285-354.

969 Yano O, Ikeda H, Watson MF, Rajbhandari KR, Jin X-F, Hoshino T, Muasya AM, Ohba

970 H. 2012. Phylogenetic position of the Himalayan genus Erioscirpus (Cyperaceae)

971 inferred from DNA sequence data. Botanical Journal of the Linnean Society 170:1-11.

$972 \quad$ DOI 10.1111/j.1095-8339.2012.01255.x

973 Zhen LS, Liang S, Tucker GC. 2010. Trichophorum Persoon. Flora of China, 176-178.

974

975 


\section{Figure 1}

Maximum likelihood (ML) tree resulting from the combined analysis of matK and ndhF plastid sequences.

Numbers above branches are parsimony bootstrap values and numbers below branches are ML bootstrap values. Open circles represent branches that collapsed in the parsimony strict consensus. The names of major Scirpo-Caricoid Clades (see text) are given to the right of species names. Numbers after species epithets correspond to specific vouchers in Table S1. Samples of Trichophorum scabriculme are shaded in grey to illustrate their position in the Trichophorum Clade as are species of Eriophorum s.str. and Erioscirpus comosus to highlight their clear separation from $T$. scabriculme. 


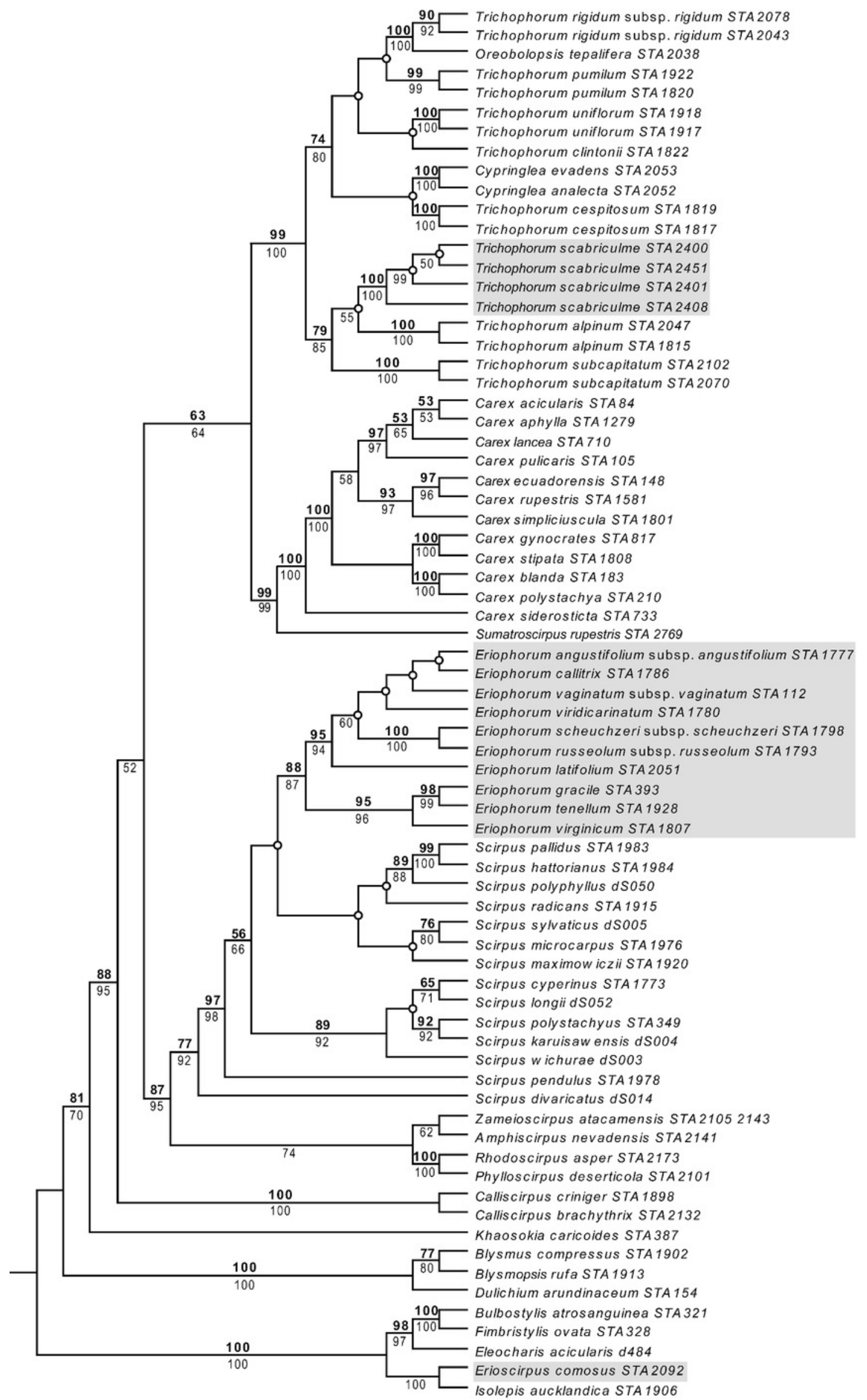

Trichophorum

Clade

Cariceae

- Sumatroscirpeae

Scirpus+Eriophorum Clade

Zameioscirpus

Clade

\section{Calliscirpus}

Khaosokia

Dulichieae

Outgroup 
Figure 2

Sagittal view of the Carex-type embryo of Trichophorum scabriculme (B. Ford 1225, J. Starr \& J. Regalado, WIN). Scale bar $=100 \mu \mathrm{m}$.
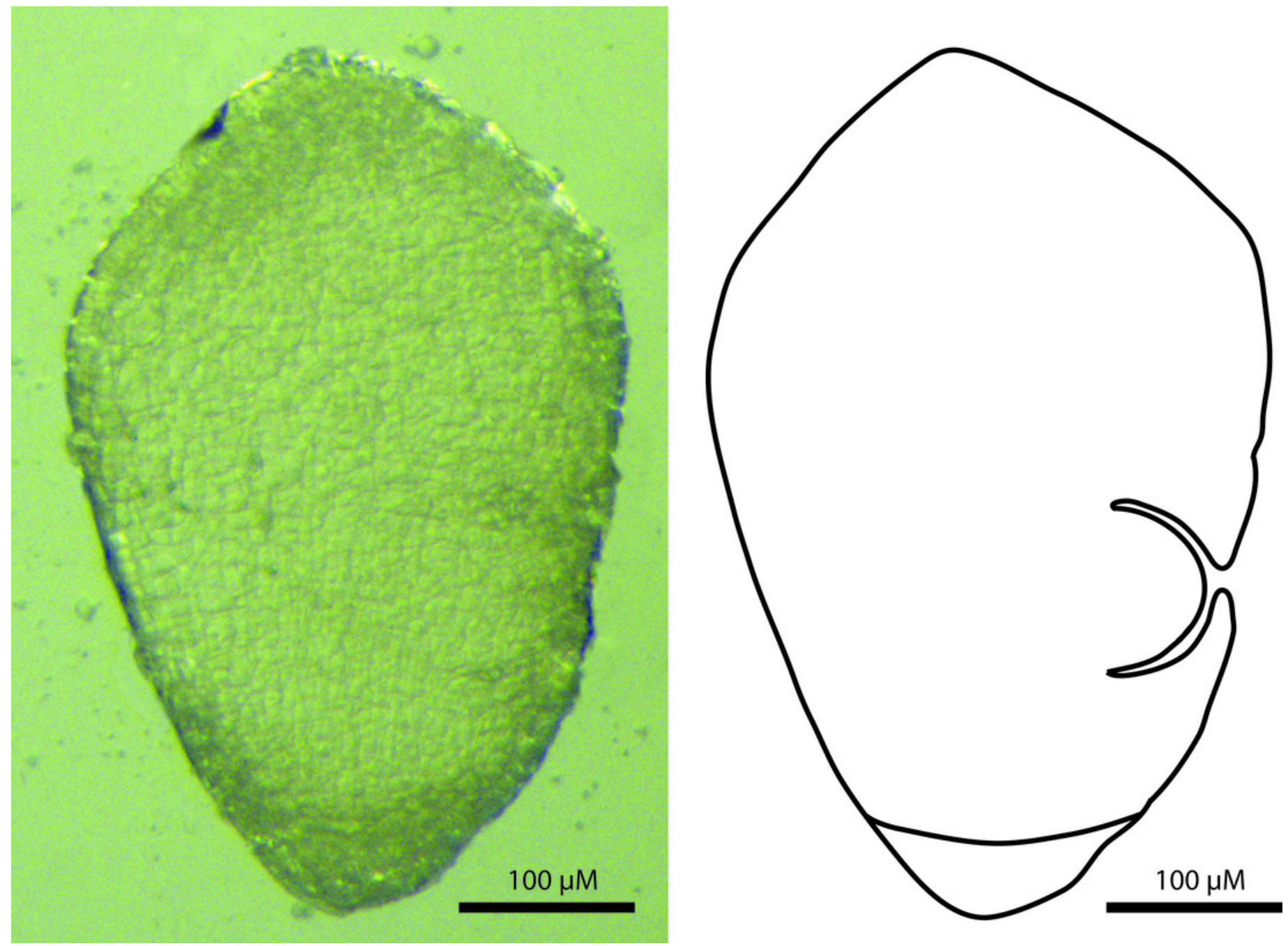


\section{Figure 3}

Illustration of Trichophorum scabriculme.

(A) Habit. (B) Inflorescence with three spikelets. (C) Bract with antrorsely scabrous awn. (D) Glume (proximal) with awn, abaxial and lateral views. (E) Flower with developing bristles (note single stamen). (F) Bristles, showing minute distally antrorse barbs. (G) Stamen, adaxial and abaxial views. (H) Gynoecium (note style branches with abundant large papillae as long as wide). (I) Nutlet (mature) with full length bristles. (J) Nutlet (mature), close up with abbreviated bristles. Nutlet (mature), in cross-section and with abaxial and lateral views. Drawn from Ford 1227A \& al. (WIN). Illustration by Bobbi Angell. 


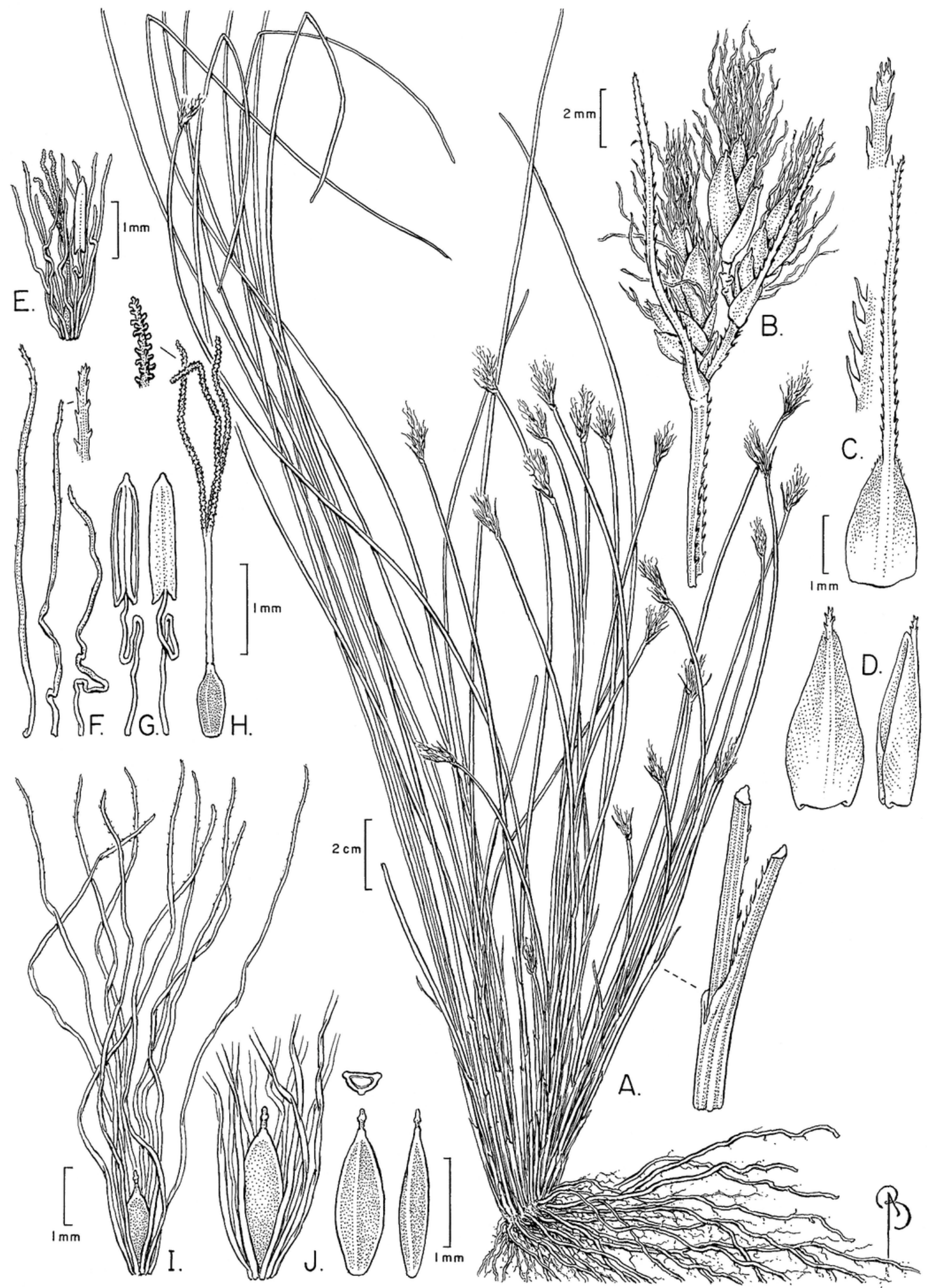


Figure 4

Distribution of Trichophorum scabriculme in the two northern Vietnamese provinces of Lai Châu and Lào Cai with China to the north.

Closed circles represent collection sites with the open circle representing the type locality, "La Cascade", which is known today as Tiên Sa Waterfall (see text). Hoàng Liên National Park is in grey with mount Phan Xi Păng and the town of Sa Pa indicated on the map. Inset shows the area covered relative to the whole of Indochina. Scale bar is for $30 \mathrm{Km}$. Map redrawn from SimpleMappr.

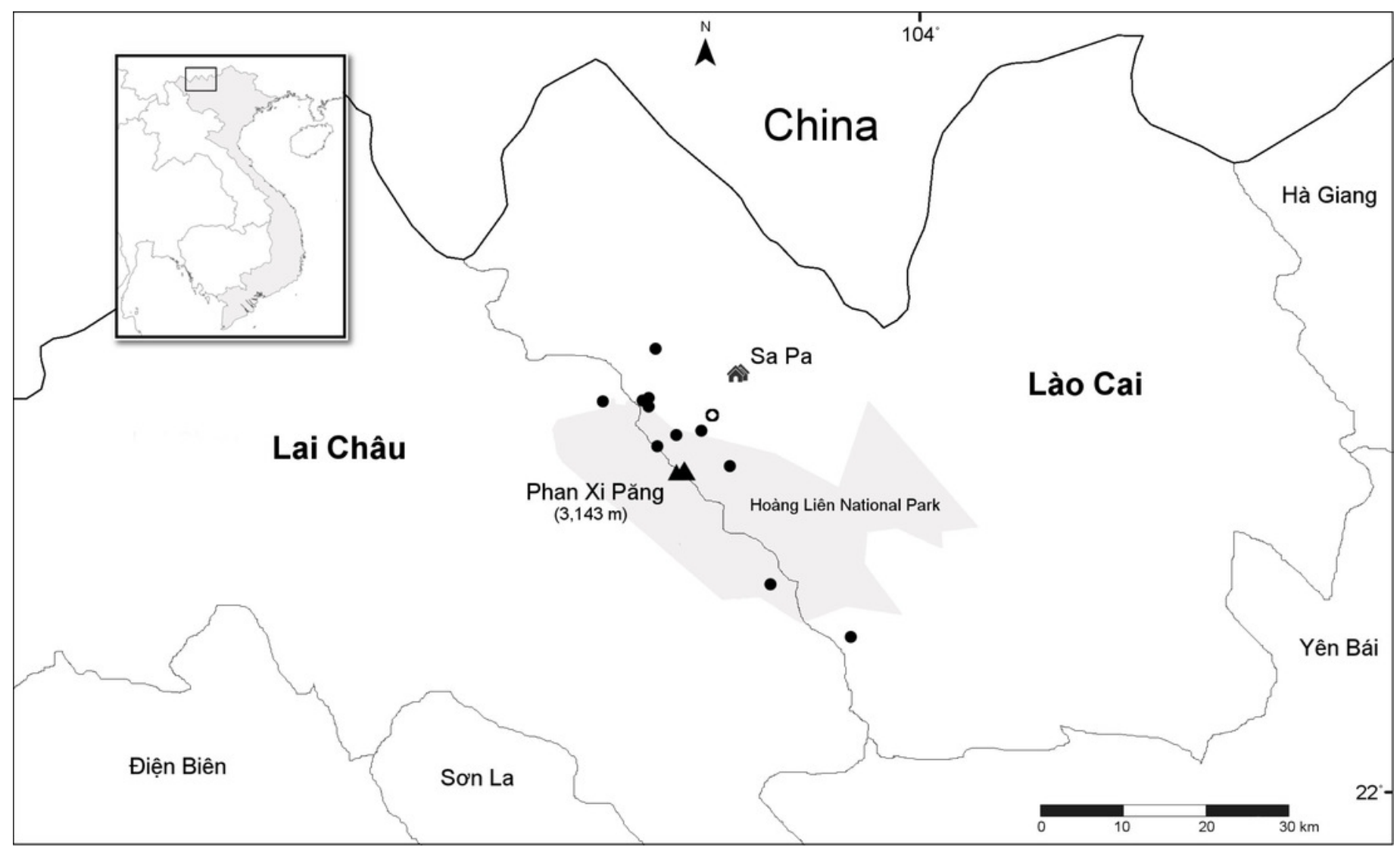




\section{Figure 5}

Habitat of Trichophorum scabriculme.

(A) The largest population observed in Vietnam on the right bank of the suối Vàng (Gold

Stream). The arrows indicate plants on cliff face. The picture is taken from the type locality for Trichophorum scabriculme ("La Cascade") with the French power station constructed in 1925 visible in the lower left corner. (B) Plants growing in fissures on edge of waterfall. (C) Plants growing in mossy substrate. Photo credit: Julian Starr.

A

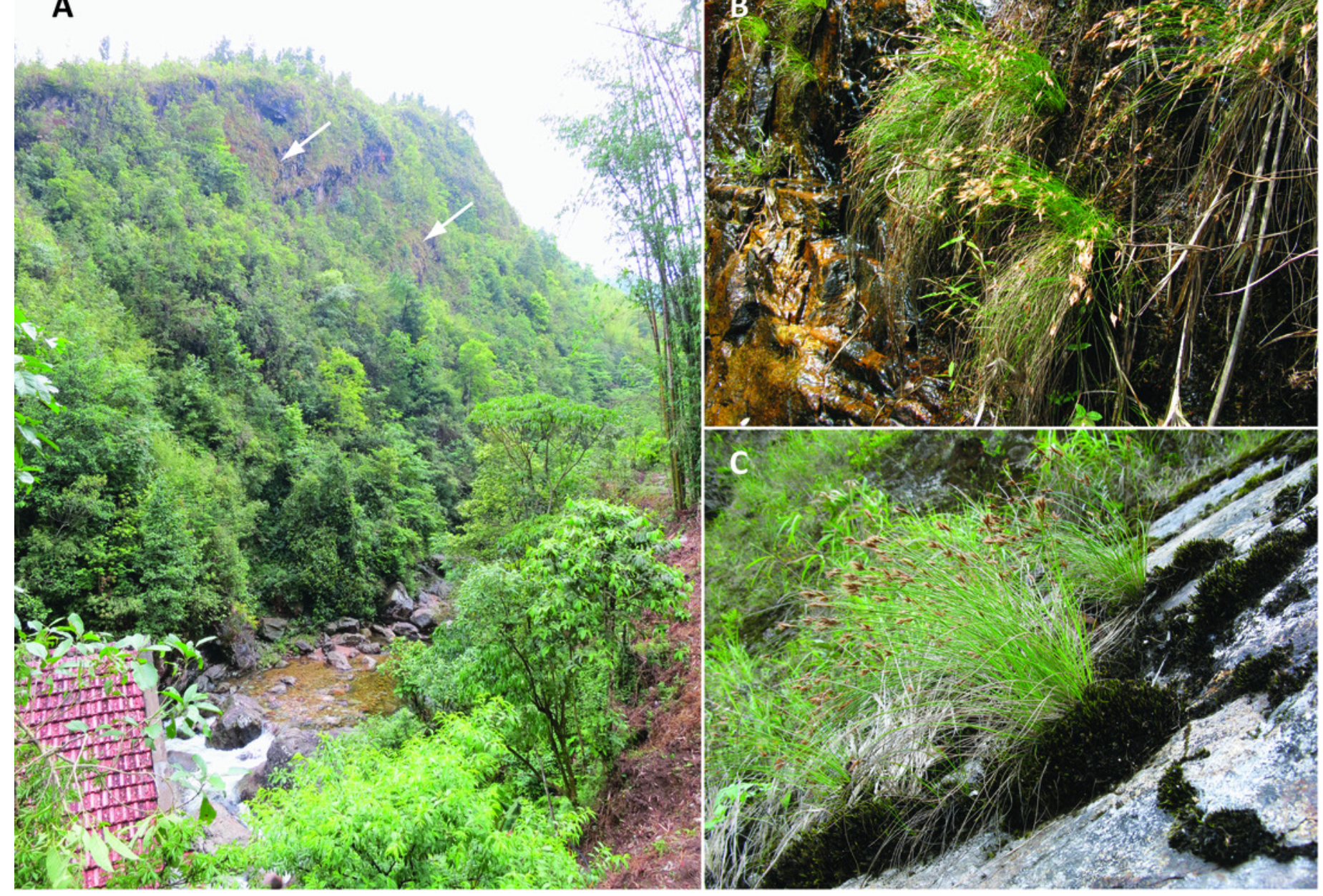


Figure 6

Anthropogenic threats to known populations of Trichophorum scabriculme.

(A) Hydrological change (2012 versus 2015). (B) Threat of widening well-traveled roads.

Photo credit: Julian Starr. 


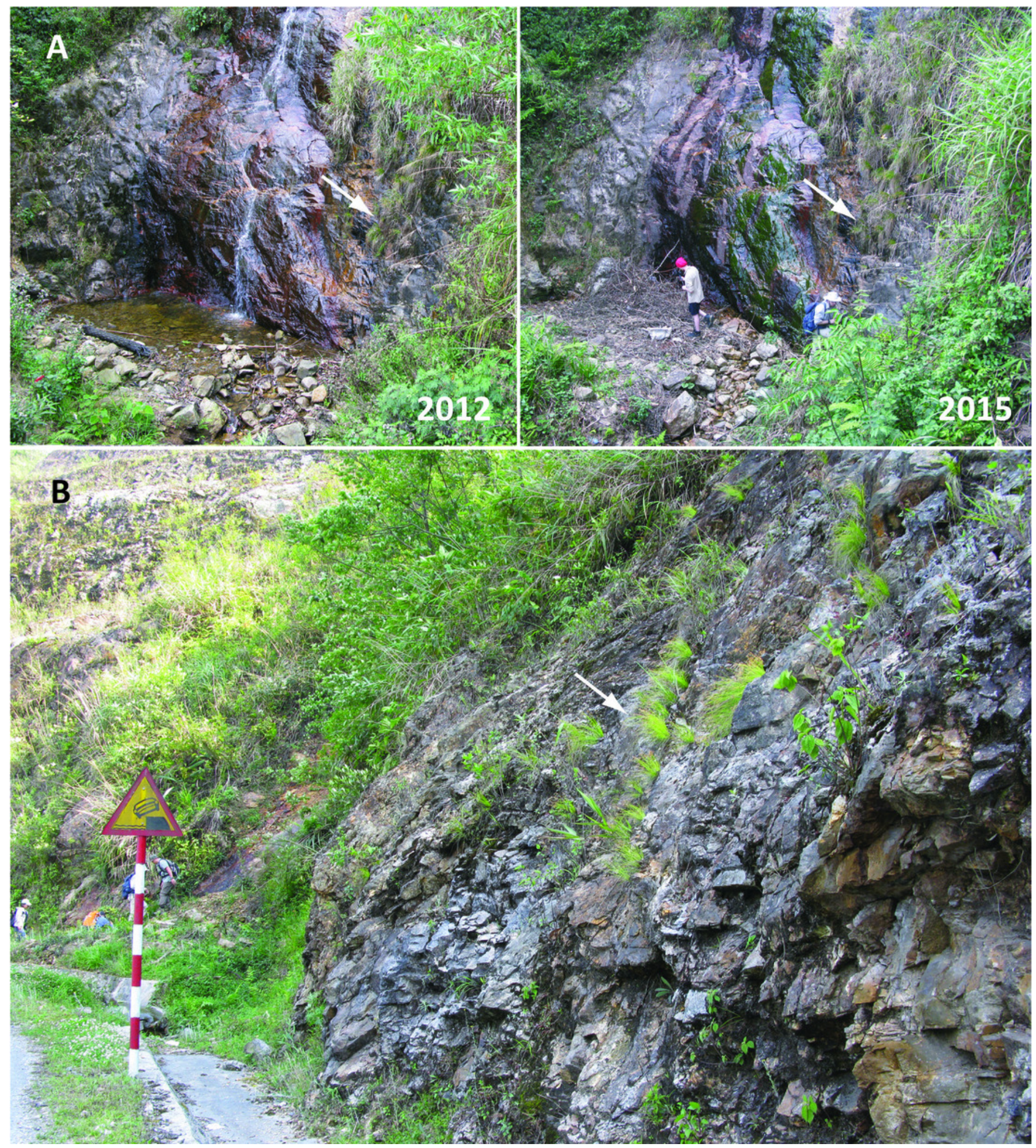




\section{Table 1 (on next page)}

Comparison of important morphological characters of genera that have been associated with Trichophorum scabriculme. 


\begin{tabular}{|c|c|c|c|c|c|}
\hline Character & Trichophorum & $\begin{array}{c}T . \\
\text { scabriculme }\end{array}$ & $\begin{array}{l}\text { Scirpus } \\
\text { s.str. }\end{array}$ & $\begin{array}{l}\text { Eriophorum } \\
\text { s.str. }\end{array}$ & Erioscirpus \\
\hline $\begin{array}{l}\text { Roots disintegrating into } \\
\text { tough black wiry strands }\end{array}$ & never & never & never & never & yes \\
\hline Basal sheaths color & $\begin{array}{l}\text { green- } \\
\text { yellowish } \\
\text { brown }\end{array}$ & $\begin{array}{l}\text { green- } \\
\text { yellowish } \\
\text { brown }\end{array}$ & $\begin{array}{l}\text { green- } \\
\text { yellowish } \\
\text { brown }\end{array}$ & $\begin{array}{l}\text { green- } \\
\text { yellowish } \\
\text { brown }\end{array}$ & $\begin{array}{c}\text { dark } \\
\text { brown/marro } \\
\text { on }\end{array}$ \\
\hline Leaves & basal & basal & $\begin{array}{l}\text { basal and } \\
\text { cauline }\end{array}$ & $\begin{array}{l}\text { basal and } \\
\text { cauline } \\
\text { (sometimes } \\
\text { basal only) }\end{array}$ & basal \\
\hline Leaf blade & $\begin{array}{l}\text { much reduced, } \\
\text { rarely well } \\
\text { developed }\end{array}$ & $\begin{array}{l}\text { much } \\
\text { reduced }\end{array}$ & $\begin{array}{c}\text { well } \\
\text { developed }\end{array}$ & $\begin{array}{c}\text { well } \\
\text { developed }\end{array}$ & $\begin{array}{c}\text { well } \\
\text { developed }\end{array}$ \\
\hline Ligule & Present & Present & Present & Present & Absent \\
\hline $\begin{array}{l}\text { Basal bract length } \\
\text { compared to inflorescence } \\
\text { (when present) }\end{array}$ & shorter-longer & $\begin{array}{l}\text { mostly } \\
\text { longer }\end{array}$ & about equal & about equal & much longer \\
\hline $\begin{array}{l}\text { Inflorescence branch habit } \\
\text { (when present) }\end{array}$ & upright & upright & $\begin{array}{l}\text { upright- } \\
\text { drooping }\end{array}$ & drooping & upright \\
\hline $\begin{array}{l}\text { Number spikelets per } \\
\text { inflorescence }\end{array}$ & $1-6)$ & $1-3$ & $50+$ & $1-3(-30)$ & $1-50+$ \\
\hline Cauline leaves & 0 & 0 & many & $(0-)$ many & 0 \\
\hline First glume differentiation & $\begin{array}{l}\text { mostly longer, } \\
\text { mucronate or } \\
\text { awned }\end{array}$ & $\begin{array}{l}\text { longer, } \\
\text { awned }\end{array}$ & $\begin{array}{l}\text { undifferentia } \\
\text { ted }\end{array}$ & $\begin{array}{l}\text { undifferentiat } \\
\text { ed }\end{array}$ & $\begin{array}{l}\text { undifferentia } \\
\text { ted }\end{array}$ \\
\hline Sterile proximal glume(s) & $1(-2)$ & 1 & 0 & $0(-$ many $)$ & 0 \\
\hline Number perianth parts & $0-6$ & $10-14$ & $0-6$ & $\geq 10$ & $>10$ \\
\hline Perianth colour & whitish & reddish & whitish & white-red & grey \\
\hline $\begin{array}{l}\text { Perianth cross-section } \\
\text { shape }\end{array}$ & $\begin{array}{l} \pm \text { terete- } \\
\text { flattened }\end{array}$ & flattened & \pm terete & flattened & \pm terete \\
\hline Perianth barbs at apex & $\begin{array}{l}\text { absent or } \\
\text { "crown" of } \\
\text { sharp teeth }\end{array}$ & $\begin{array}{l}\text { "crown" of } \\
\text { sharp teeth }\end{array}$ & $\begin{array}{c}\text { absent or a } \\
\text { few retrorse } \\
\text { barbs } \\
\text { forming a } \\
\text { "harpoon" }\end{array}$ & $\begin{array}{l}\text { "crown" of } \\
\text { sharp teeth }\end{array}$ & $\begin{array}{c}2-3 \\
\text { divaricate } \\
\text { teeth forming } \\
\text { a "grappling- } \\
\text { hook" }\end{array}$ \\
\hline Perianth barbs below apex & $\begin{array}{l}\text { absent or } \\
\text { present, }\end{array}$ & $\begin{array}{l}\text { antrorse, } \\
\text { sharp }\end{array}$ & $\begin{array}{l}\text { Absent or } \\
\text { present, }\end{array}$ & absent & patent, blunt \\
\hline
\end{tabular}




\begin{tabular}{|c|c|c|c|c|c|}
\hline & $\begin{array}{c}\text { antrorse or } \\
\text { patent, blunt or } \\
\text { sharp }\end{array}$ & & $\begin{array}{l}\text { antrorse or } \\
\text { retrorse, } \\
\text { sharp or } \\
\text { blunt }\end{array}$ & & \\
\hline Anther apiculum & small, oblong & $\begin{array}{l}\text { small, } \\
\text { oblong }\end{array}$ & $\begin{array}{l}\text { small, } \\
\text { oblong }\end{array}$ & small, oblong & $\begin{array}{l}\text { long, } \\
\text { acuminate }\end{array}$ \\
\hline Embryo root cap position & basal & basal & lateral & lateral & lateral \\
\hline $\begin{array}{l}\text { Embryo germ pore } \\
\text { orientation (in relation to } \\
\text { first leaf) }\end{array}$ & perpendicular & $\begin{array}{c}\text { perpendicula } \\
\mathrm{r}\end{array}$ & $\begin{array}{c}\text { perpendicula } \\
\mathrm{r}\end{array}$ & perpendicular & parallel \\
\hline
\end{tabular}

1 